\title{
Arah Kiblat di Planet Mars
}

\author{
M. Ikhtirozun Ni’am \\ ihtirozun_n@yahoo.co.id
}

\begin{abstract}
Abstrak
Dalam beberapa dekade akhir ini, upaya untuk mencari adanya kehidupan di luar Bumi gencar dilakukan. Planet Mars dalam hal ini menjadi sasaran utama untuk dideteksi adanya kemungkinan kehidupan di dalamnya. Karena planet Mars dianggap sebagai planet yang mirip dengan Bumi di bandingkan dengan planet-planet lain di tata surya. Mulai dari tahun 1962, ilmuwan mengirimkan pesawat ruang angkasa Mars-1 untuk mendeteksi adanya kehidupan di planet Mars.

Misi tersebut dilanjutkan dengan mengirimkan pesawat ruang angkasa Mars-2 pada tahun 1971 dan Mars-3 pada tahun 1972. Pada tahun 1965, dilanjutkan dengan penyelidikan Mariner 4. Dari Mariner 4 ini diperoleh foto-foto permukaan planet Mars untuk pertama kalinya. Misi lainnya yaitu dengan mengirimkan viking orbiters, viking experiment, phoenix lander pada tahun 2008 dan Misi Mars Science Laboratory dengan mengirimkan penjelajah Coriousity pada tanggal 26 November 2011. Ke depan, misi ini akan dilanjutkan dengan mengirimkan pesawat ruang angkasa Exo Mars, Penjelajah Mars 2020 (Mars Rover 2020) dan misi Mars One. Misi Mars One ini bertujuan untuk menciptakan koloni manusia di planet Mars. Jadi, manusia yang dikirimkan ke planet ini tidak akan dikembalikan lagi ke Bumi, melainkan akan menetap di planet Mars. Misi ini akan dimulai pada tahun 2023 dengan mengirimkan 4 peserta yang lolos seleksi dan dilanjutkan 2 peserta lainnya setiap 2 tahun sekali.

Sampai pada bulan Februari 2014, tercatat lebih dari 200.000 manusia yang sudah mendaftarkan diri untuk mengikuti perjalanan satu arah menuju Mars ini. Dan uniknya 500 diantaranya adalah orang Arab Saudi yang notabene beragama Islam. Sehingga muncul persoalan terkait pelaksanaan peribadatan yang pada biasanya terkait dengan fenomena yang ada di Bumi, seperti harusnya menghadap Ka'bah sebagai kiblat ketika ingin menjalankan shalat. Persoalannya kemudian, masihkah diwajibkan shalat di planet Mars? Lalu kemanakah arah kiblat bagi orang yang berada di planet Mars? Bagaimana cara mencari arah kiblatnya?

Dalam penelitian ini, akan diungkapkan nantinya sejauh mana ruang lingkup keberlakuan syari'ah sehingga menjadi jelas dimana saja kewajiban tersebut masih wajib dilaksanakan. Selanjutnya juga akan diungkapkan kemanakah arah kiblatnya dan bagaimana cara menentukan arah kiblatnya.

Dari kajian tersebut, ditemukan bahwa : (1) Syari'at masih tetap berlaku meskipun berada di planet Mars, sehingga orang yang berada di planet Mars masih dikenai kewajiban untuk melakukan shalat. (2) Arah kiblat bagi orang yang berada di planet Mars adalah Bumi atau proyeksi garis koordinat Bumi. (3) Untuk mengetahui arah atau azimuth bumi dari planet Mars, terlebih dahulu harus ditentukan waktu pengukuran dan koordinat geografis tempat di Mars yang akan diukur arah kiblatnya. Selanjutnya harus diperhitungkan nilai koordinat ekliptika planet Mars, Bumi, nilai koordinat Areosentrik Bumi, termasuk juga Nilai Jarak Bumi ke Mars, Nilai Asensiorekta Bumi dari Mars, Nilai Deklinasi Bumi dari Mars, nilai sudut elongasi bumi -Matahari, nilai Fraksi Iluminasi Bumi, Nilai Semidiameter Bumi dari Mars, nilai Lebar Piringan Bumi dari Mars, Nilai Equation of time, Nilai Azimuth dan
\end{abstract}


Altitude Bumi, Nilai dan Azimuth Matahari. Dari situ akan ditemukan dimana posisi Bumi dilihat dari Mars.

\section{Kata Kunci : Arah kiblat, Mars, Bumi, Perhitungan}

\section{A. Prolog}

Pada tanggal 14 Mei 2013, situs www.astronomi.us mengabarkan bahwa lebih dari 78.000 orang telah menaftarkan diri untuk pergi ke Mars. ${ }^{1}$ Angka ini terus bertambah. Sampai saat dilakukannya penelitian ini (tanggal 5 Februari 2014), sudah mencapai angka 200 ribu orang yang bersedia menjadi tukang "babat alas" di planet merah tersebut ${ }^{2}$. Mereka datang dari lebih dari 120 negara yang berbeda. Uniknya, 500 orang dari mereka adalah orang Arab Saudi yang notabenya adalah beragama Islam.

Yang menjadi perhatian di sini, misi Mars One ini bukan untuk perjalanan pulang pergi, namun lebih dari itu, mereka akan tetap tinggal di mars, tidak kembali ke Bumi. ${ }^{3}$ Itulah yang dikatakan Lansdorp. Karena menurutnya, misi Mars One ini ditujukan untuk membangun koloni manusia permanen di planet Mars. Jadi, mereka tidak akan kembali ke Bumi. Rencananya, misi kolonoi pertama akan dilangsungkan pada tahun 2023 dengan 4 orang yang akan dipilih dari sekian banyaknya pendaftar. Dilanjutkan dengan misi koloni kedua pada tahun 2025 dan berturut-turut 2 tahun sekali setelahnya.

Terlepas dari itu semua, kemungkinan adanya sebuah kehidupan di luar bumi telah diisyaratkan oleh al-Qur'an. Dalam surat ar-Ra'd ayat 15 disebutkan :

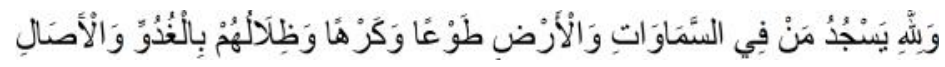

(Artinya : Dan semua sujud kepada Allah baik yang dilangit maupun yang di bumi, baik dengan kemampuan sendiri maupun terpaksa (dan sujud pula) bayang-bayang mereka, pada waktu pagi dan petang hari)(Ar-Ra'd:15)

Pemaikaian isim maushul "man" mengindikasikan bahwa makhluk hidup yang dimaksud adalah makhluk hidup yang berakal. Dan mereka pun mempunyai bayang-bayang, yang artinya bukan jin atau pun malaikat, namun makhluk hidup sejenis manusia. ${ }^{5}$ Mengenai manakah tempat yang di maksud kata as-samawat, diduga jawabannya adalah planet-planet yang tersebar di ruang angkasa luas di luar bumi. Yang mana tempat-tempat tersebut mesti mengandung beragam hal yang diperlukan bagi terwujudnya kehidupan, seperti air, oksigen, bahan makan dan lain sebagainya. ${ }^{6}$ Dan telah diketahui bahwa di ruang angkasa terdapat milyaran galaksi yang terbentuk dari bintang atau planet yang tidak terhitung jumlahnya. Setiap gugusan bintang ini tentu memiliki karakter-karakter yang serupa antara yang satu dengan lainnya, walaupun mestinya keadaan itu tidak persis sama. ${ }^{7}$ Karena itu,

\footnotetext{
${ }^{1}$ http://www.astronomi.us/2013/05/lebih-dari-78-ribu-orang-mendaftar.html, diakses pada tanggal 8 Januari 2014, jam : 20:28

${ }^{2}$ http://www.merdeka.com/teknologi/200-ribu-orang-siap-jadi-warga-planet-mars.html diakses pada tanggal 8 Januari 2014, jam : 21:05

${ }^{3}$ Op.cit.

${ }^{4}$ Kementrian Agama RI, Tafsir Ilmi Penciptaan Jagad Raya Dalam Prespektif Al-Qur'an dan Sains, Jakarta : PT. Sinergi Pustaka Indonesia, 2012, hal. 106

${ }^{5}$ Ibid, hal. 105

${ }^{6}$ Ibid, hal. 106

${ }^{7}$ Ibid
} 
adanya planet-planet yang keadaanya serupa dengan Bumi merupakan suatu keniscayaan yang tidak diragukan. Dengan demikian, adanya kehidupan di tempattempat tersebut sangat memungkinkan. ${ }^{8}$

Hal ini dibenarkan dengan adanya temuan-temuan dari para ilmuwan. NASA (Badan Antariksa Amerika Serikat) menyatakan tentang adanya kehidupan mikroskopis di planet Mars. ${ }^{9}$ Wahana Mars Reconnaissance Orbiter (MRO) yang saat ini sedang mengorbit planet Mars mengabadikan gambar adanya aliran aluvial yang terbentuk oleh air pada jutaan tahun yang lalu dengan memakai kamera HiRISE (High Resolution Imaging Science Experiment). Aliran ini ditemukan di sebuah daerah di dekat kawah Mojave di ekuator Mars ${ }^{10}$.

Bukti tersebut dikuatkan dengan temuan Curiosity, sebuah robot penjelajah Mars milik NASA. Curiosity menemukan adanya batuan/kerikil yang menempel pada batuan konglomerat sebagai hasil dari aliran air. Kerikil tersebut diperkirakan terbawa oleh aliran air dengan kecepatan sekitar 1 meter per detik dengan kedalaman bervariasi mulai dari se-mata kaki sampai se-pinggang orang dewasa. ${ }^{11}$

Rebecca Williams, ilmuwan penyelidik Curiosity mengatakan bahwa kerkil tersebut tidak dibawa oleh angin, namun dibawa oleh aliran air. ${ }^{12}$ Bukti tersebut ditemukan di sebelah utara dari tepi kawah Gale dan di bawah Gunung Aeolis Mons atau Mount Sharp. Sebelah utara kawah terdapat sebuah saluran bernama Peace Vallis yang mengalir ke saluran-saluran yang lebih kecil. ${ }^{13}$ Adanya air ini, menurut alQur'an mengindikasikan adanya makhluk hidup di tempat tersebut dan juga tempat tersebut bisa dijadikan sebagi tempat untuk hidup atau tempat yang mempunyai sumber kehidupan. Dalam surat an-Nur ayat 45 disebutkan :

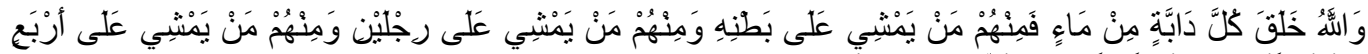

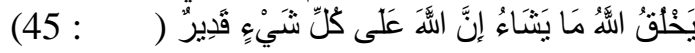

(Artinya : Dan Allah telah menciptakan semua jenis hewan dari air, maka sebagian dari hewan itu ada yang berjalan di atas perutnya dan sebagian berjalan dengan dua kaki sedang sebagian (yang lain) berjalan dengan empat kaki. Allah menciptakan apa yang dikehendaki-Nya, sesungguhnya Allah Maha Kuasa atas segala sesuatu). ${ }^{14}$

Dengan demikian possibility untuk bisa hidup di planet Mars sangatlah besar. Masalahnya kemudian, bagaimana dengan ketentuan-ketentuan syari'at yang pada waktu itu memakai paradigma al-ardh (bumi) saja. Sebagaimana yang tercerminkan dalam hadist yang diriwayatkan oleh Ibnu 'Abbas tentang arah kiblat. Dalam hadist tersebut disebutkan :

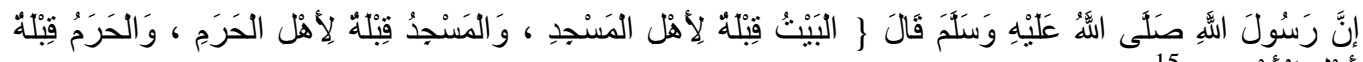

\footnotetext{
${ }^{8}$ Ibid

${ }^{9}$ Ibid, hal. 105

${ }^{10} \mathrm{http}: / /$ www.astronomi.us/2013/08/bukti-paling-nyata-air-pernah-ada-di.html

${ }_{11} \mathrm{http}: / /$ www.astronomi.us/2012/09/curiosity-temukan-batuan-yang-buktikan.html

12 Op.cit

${ }^{13}$ Ibid

${ }^{14}$ Kementrian Agama RI, Log.cit, hal. 105

${ }^{15}$ Muhammad bin Muhammad bin Muhammad bin 'Abdur Rahman Ar-Ra'ini, Mawahib Al-
} Jalil, Daru 'Alim al-Kutub, 2003, juz. 2, hal. 199 
(Artinya : Sesungguhnya Rasulullah SAW bersabda, "Baitullah (Ka'bah) adalah kiblat bagi orang yang berada di Masjidil Haram, dan Masjidil Haram adalah kiblat bagi orang yang berada di tanah haram (Makkah), dan tanah haram (Makkah) adalah kiblat bagi penduduk Bumi)

Dalam hadist tersebut tidak disebutkan secara eksplisit bagaimana kiblatnya orang yang berada di luar Bumi, seperti Mars misalnya.

Maka hal ini akan menjadi sebuah permasalahan jikalau dengan kecanggihan tekhnologi masa kini memungkinkan penduduk Bumi untuk berpindah ke planet Mars. Pertama, apakah bagi umat Islam yang berada di Mars masih dikenai kewajiban untuk melakukan shalat? Kalaupun iya, manakah arah kiblat tempat ia menghadap saat shalat? Pertanyaan-pertanyaan ini akan dibahas dalam penelitian ini dengan judul "Arah Kiblat Di Planet Mars".

\section{B. Antusiasme dan Prospek Hidup di Planet Mars}

Harun Yahya dalam bukunya "Pesona Di Angkasa Raya" menyebutkan bahwa hanya planet Bumi-lah satu-satunya planet yang memungkinkan adanya kehidupan. Selain itu, dia juga mengungkapkan bahwa tidak ada kehidupan di planet Mars.Planet Mars merupakan planet mati yang tidak pernah dibandingkan dengan Bumi. Alasanalasan yang dikemukakan adalah :

1. Atmosfir palent Mars merupakan campuran mematikan yang mengandung karbondioksida pekat;

2. Tidak ada air di sana ;

3. Suhu di planet Mars sekitar $-53^{\circ} \mathrm{C}\left(-63^{\circ} \mathrm{F}\right)$;

4. Terdapat angin yang sangat kuat serta badai pasir yang terjadi setiap saat. ${ }^{16}$

Namun dari itu, para ahli eksobiologi ${ }^{17}$ mempunyai analisis yang berbeda dengan apa yang disampaikan oleh Harun Yahya. Mereka meyakini bahwa beberapa bentuk kehidupan mungkin ada di Planet Mars. Pendapat ini didasarkan pada beberapa argumen yang mendasarinya, yaitu :

1. Radiasi ultraviolet mudah dihadang oleh rintangan fisik;

2. Oksigen, nitrogen dan air mungkin terdapat dalam jumlah yang cukup guna membantu kehidupan organisme yang kuat seperti bakteri dan lumut;

3. Adanya sebuah lapisan air yang tetap beku (bekuperma) di bawah permukaan tanah tampaknya mungkin dan mungkin meleleh di tempat-tempat tertentu dari waktu ke waktu sehingga dapat tersedia air buat benda hidup;

4. Nitrogen dapat saja terbentuk dalam jumlah kecil di dalam atmosfer; di dalam tanah juga mungkin terdapat garama-garam yang mengandung nitrogen;

5. Berdasarkan hasil uji coba labolatorium dengan berbagai keadaan lingkungan Mars tiruan, organisme-organisme seperti bakteri, ganggang, lumut, lumut padas, beberapa tanaman dari kelas yang lebih tinggi, dan serangga terbukti masih dapat hidup.

Dalam hal adanya kemungkinan kehidupan di luar Bumi, al-qur'an juga memberi isyarat akan hal ini. Dalam surat ar-Ra'd ayat 15 disebutkan :

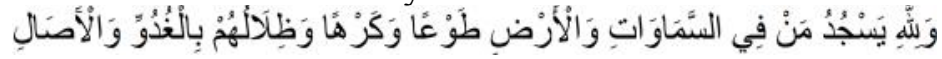

\footnotetext{
${ }^{16}$ Harun Yahya, Pesona Di Angkasa Raya, e-book.

${ }^{17}$ Eksobiologi secara harfiah berarti biologi luar (bumi), yatu ilmu yang lebih lanjut membahas asalusul kehidupan. Lihat artikel Richard S. Young berjudul Kehidupan di Dunia Lain dalam buku Ilmu Pengetahuan Populer, hal. 34
} 
(Artinya : Dan semua sujud kepada Allah baik yang dilangit maupun yang di bumi, baik dengan kemampuan sendiri maupun terpaksa (dan sujud pula) bayang-bayang mereka, pada waktu pagi dan petang hari)(Ar-Ra'd:15) ${ }^{18}$

Pemaikaian isim maushul "man" menunjukkan bahwa makhluk hidup yang dimaksud adalah makhluk hidup yang berakal. Dan mereka pun mempunyai bayangbayang, yang artinya bukan jin atau pun malaikat, namun makhluk hidup sejenis manusia. ${ }^{19}$ Mengenai manakah tempat yang di maksud kata as-samawat, diduga jawabannya adalah planet-planet yang tersebar di ruang angkasa luas di luar bumi. Yang mana tempat-tempat tersebut mesti mengandung beragam hal yang diperlukan bagi terwujudnya kehidupan, seperti air, oksigen, bahan makan dan lain sebagainya. ${ }^{20}$ Dan telah diketahui bahwa di ruang angkasa terdapat milyaran galaksi yang terbentuk dari bintang atau planet yang tidak terhitung jumlahnya. Setiap gugusan bintang ini tentu memiliki karakter-karakter yang serupa antara yang satu dengan lainnya, walaupun mestinya keadaan itu tidak persis sama. ${ }^{21}$ Karena itu, adanya planet-planet yang keadaanya serupa dengan Bumi merupakan suatu keniscayaan yang tidak diragukan. Dengan demikian, adanya kehidupan di tempat-tempat tersebut sangat memungkinkan. ${ }^{22}$

Terlepas dari itu, antusiasme penduduk Bumi untuk mencari kehidupan di luar Bumi, khususnya di planet Mars sangatlah tinggi. Ini terlihat dari upaya-upaya yang ditempuh mulai dari tahun 1961 sampai sekarang dan upaya-upaya yang dirancang untuk masa depan. Diantara upaya-upaya tersebut adalah :
a. Mars-1, Mars-2 dan Mars-3
b. Mariner 4
c. Viking Orbiter
d. Viking Eksperiment
e. Phoenix Lander, 2008
f. Mars Science Laboratory
g. Exo Mars
h. Misi Penjelajahan Mars 2020
i. Misi Pengambilan Sampel Planet Mars

\section{Ruang Lingkup Pemberlakuan Hukum Shalat}

Dalam surat al-Anbiya' ayat 107 disebutkan :

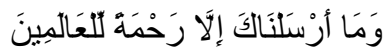

Artinya : Dan tiadalah Kami mengutus kamu, melainkan untuk (menjadi) rahmat bagi semesta alam.

Mengenai maksud dari kata "'alamiina” Ibnu Mandhur dalam Lisanul 'arab menyebutkan :

$$
\text { كلُه وقيل هو ما احتو اه بطنُ الفَلك }
$$

(Yang dimaksud 'alam adalah semua ciptaan Allah. Dan ada yang mengatakan bahwa 'alam adalah: segala sesuatu yang tercangkup dalam orbit)

$$
\text { التنزيل الحمد لله ربّّ العالمين قال ابن عباس رَبّ الجن و الإنس وقال قتادة رب الخلق كلهم }
$$

\footnotetext{
${ }^{18}$ Kementrian Agama RI, Tafsir Ilmi Penciptaan Jagad Raya Dalam Prespektif Al-Qur'an dan
} Sains, Jakarta : PT. Sinergi Pustaka Indonesia, 2012, hal. 106

${ }^{19}$ Ibid, hal. 105

${ }^{20}$ Ibid, hal. 106

${ }^{21}$ Ibid

${ }^{22}$ Ibid 
Dalam ayat "Alhamdulillahi rabbil 'alamin, Ibnu 'Abbas menafsirinya Tuhan jin dan manusia. Qatadah mengatakan bahwa yang dimaksud adalah Tuhan semua makhluk/ciptaan)

$$
\text { وروي عن و هب بن منبه أنه قال لله تعالى ثمانية عشر ألفَ عالَم الدنيا منها عالَّم }
$$

Dan diriwayatkan dari Wahab bin Manbah bahwasanya Nabi bersabda, "Allah ta'ala mempunyai 80.000 'alam dunia, diantara ada alam yang satu.

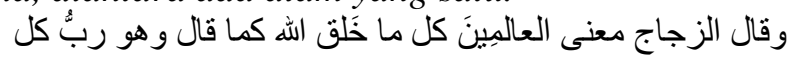

Az-zujaj mengatakan bahwa makna al-'alamiina adalah semua yang diciptakan oleh Allah sebagaimana ucapan bahwa Allah adalah tuhan segala sesuatu

Ibnu katsir dalam kitabnya tafsir Ibnu Katsir menyebutkan :

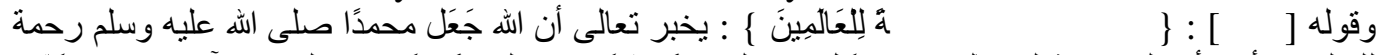

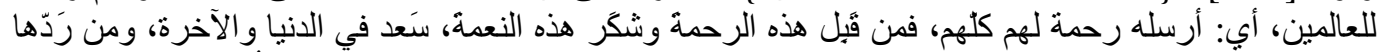

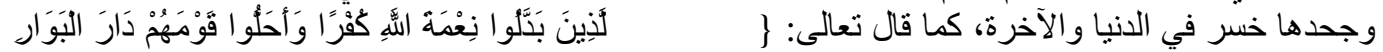

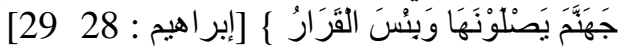

Firman Allah Ta'ala, "wa maa arsalnaaka illa rahmatan lil 'alamina” memberikan kabar bahwa Allah menjadikan Nabi Muhammad SAW. sebagai rahmat bagi semua alam, maksudnya ia diutus sebagai rahmat bagi semua alam. Barang siapa yang menerima rahmat ini dan mensyukuri nikmat ini, ia akan bahagia di dunia dan akhirat. Dan barang siapa yang menolak dan menetangnya, ia akan merugi di dunia dan akhirat sebagaimana firman Allah ta'ala: "Tidakkah kamu perhatikan orangorang yang telah menukar nikmat Allah dengan kekafiran dan menjatuhkan kaumnya ke lembah kebinasaan?, yaitu neraka jahannam; mereka masuk kedalamnya; dan itulah seburuk-buruk tempat kediaman.

Dari pemaparan di atas dapat diketahui bahwa dalam menafsirkan ayat "wa maa arsalnaaka illa rahmatan lil 'alamin" ada yang mengkaitkannya dengan dimensi personal, yakni manusia dan jin. Dan ada pula yang mengkaitkannya dengan dimensi ruang, yakni seluruh alam semesta yang tercakup dalam falak (orbit).

Dengan begitu berarti kewajiban melakukan peribadatan tidak terbatas pada tempat atau ruang tertentu, namun dimana pun kita berada, peribadatan tetap wajib dilaksanakan sebagaimana dalam tuntutan untuk bertakwa. Dalam hadist yang diriwayatkan oleh Imam Tirmidzi, disebutkan bahwa tuntutan untuk bertakwa tidak terbatas pada temat tertentu, akan tetapi wajib dilakukan dimanapun kita berada.

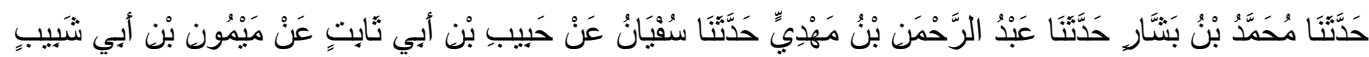

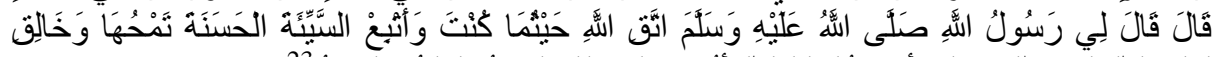

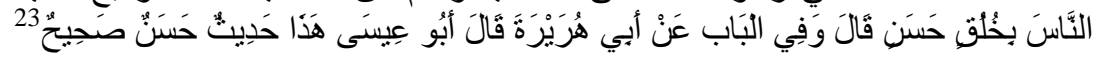

Kita diceritai oleh Muhammad bin Bassyar, kita diceritai oleh Abdurrahman bin Mahdi, kita diceeritai oleh Sufyan dari Habib bin Abi Tsabit dari Maimun dari Abi Syabib dari Abi Dzar, ia berkata, Rasulullah berkata padaku "Bertakwalah kalian kepada Allah dimanapun kalian berada, dan iringilah perbuatan buruk dengan perbuatan baik tentu akan menghapusnya dan bergaulah sesama manusia dengan akhlak yang baik. Dalam bab ini, dari Abi Hurairah, Abu Isa mengatakan bahwa hadist ini hadist Hasan dan Shahih.

${ }^{23}$ At-Tirmidzi, Sunan Tirmidzi, Maktabah Syamilah, Juz 7. Hal. 262 
Masalah ini dipertegas lagi dengan melihat filosofi penciptaan manusia. Dalam surat Adz-Dzariyat ayat 56 disebutkan bahwa manusia dan juga jin diciptakan tidak lain adalah untuk mengabdi, beribadah dan menyembah Allah.

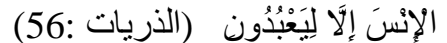 \\ " Dan Aku tidak menciptakan jin dan manusia melainkan supaya mereka menyembahKu"}

Maka dari itu, tujuan utama ini tidak bisa hilang hanya karena manusia berada di tempat yang berbeda dengan biasanya.

Shalat bisa menjadi haram dikerjakan bukan karena tempat pelaksanaanya, akan tetapi karena waktu pelaksanaanya. Dalam hal ini Zein Bin Ibrahim Bin Zein Bin Smith dalam kitab At-Taqiratus Sadidah Fi Masail al-Mufidah mengatakan bahwa saat-saat diharamkannya shalat itu ada 5, yang tiga berkaitan dengan dengan waktu dan yang 2 berkaitan dengan pekerjaan. 3 yang berkaitan dengan waktu yaitu :

1. Dari terbitnya Matahari sampai matahari setinggi tombak,

2. Dari waktu kulminasi Matahari (istiwa') sampai condong ke barat,

3. Dari menguningnya Matahari sampai tenggelam.

Adapun 2 hal yang berkaitan dengan pekerjaan yaitu :

1. Setelah mengerjakan shalat subuh sampai terbitnya Matahari,

2. Setelah mengerjakan shalat Ashar sampai tenggelamnya Matahari. ${ }^{24}$

Pentingnya shalat ini juga terlihat dari bagaimana Allah tetap mewajibkannya dalam kondisi apa pun dan bagaimana pun, baik dalam kondisi bepergian, sakit maupun perang. Orang yang sedang dalam kondisi bepergian, tetap wajib melakukan shalat meskipun boleh dengan dijamak maupun diqoshor. Orang yang sedang dalam kondisi sakit tetap wajib melakukan shalat meskipun dengan duduk ${ }^{25}$, atau tidur miring atau tidur terlentang atau dengan isyarat kelopak mata atau melakukan rukunrukun shalat di dalam hati ${ }^{26}$. Dan orang yang sedang dalam kondisi perang sesengit apapun itu, tetap masih wajib melakukan shalat, meskipun sebisanya saja, tidak seperti dalam kondisi normal, yaitu dengan memberikan isyarat ketika ruku' atau sujud dengan mengatur posisi yang lebih rendah jika sujud dan agak tinggi jika ruku', bila memungkingkan. Hal ini dilakukan dalam kondisi perang yang sudah tidak teratur, sudah bercampur aduk antara teman dan musuh. ${ }^{27}$

Tidak hanya itu, pentingnya shalat ini bisa dilihat dari bagaimana Allah memberikan ancaman terhadap orang yang meninggalkan kewajiban ini. Dalam sebuah hadist Nabi Muhammad SAW bersabda :

من ترك الصلاة لقي الله وهو عليه غضبان 28 Barang siapa yang meninggalkan shalat, Allah akan menemuinya dalam keadaan marah.

Dalam hadist lain beliau juga bersabda :

$$
\text { عمله و برئت منه ذمّة الله حتّى ير اجع اللّه عزّ وجلّ توبة }
$$

\footnotetext{
${ }^{24}$ Zein Bin Ibrahim Bin Zein Bin Smith, At-Taqiratus Sadidah Fi Masail al-Mufidah, Surabaya : Darul 'Ulum al-Islamiyyah, 2006, hal.192-193

${ }^{25}$ Syeikh Muhammad Bin Qasim, Fathul Qarib, Surabaya : Nurull Huda, tt, hal. 13

${ }^{26}$ Zein Bin Ibrahim Bin Zein Bin Smith, opcit, hal. 214

${ }^{27}$ Zein Bin Ibrahim Bin Zein Bin Smith, ibid, hal. 355

${ }^{28}$ Zein Bin Ibrahim Bin Zein Bin Smith, ibid, hal. 360

${ }^{29}$ Zein Bin Ibrahim Bin Zein Bin Smith, ibid.
} 
Barang siapa yang sengaja meninggalkan shalat, Allah akan melebur amal perbuatannya dan membebaskan tanggungan atas dirinya sehingga ia kembali kepada Allah dalam keadaan taubat.

Lebih ekstrimnya lagi, Nabi Muhammad mengatakan bahwa perbedaan antara orang muslim dan kafir adalah shalat. Ketika ia meninggalkan shalat, ia tak ubahnya seperti orang kafir.

بين الرجل و بين الكفر ترك الصيّلاة30

(Perbedaan) antara orang laki-laki (muslim) dan kafir adalah meninggalkan shalat.

Maka dari itu, bisa disimpulkan bahwa kewajiban melakukan shalat tetaplah melekat pada diri umat Islam dimanapun ia berada. Kewajiban shalat bisa berubah hukumnya ketika dikaitkan dengan waktu, bukan tempat pelaksanaanya. Dari situ, penulis menyimpulkan bahwa umat Islam masih tetap dikenai kewajiban menjalankan shalat meskipun di planet Mars. Hal ini juga sebagaimana yang dilakukan oleh Dr. Sheikh Muszaphar Shukor ketika mengikuti proyek ISS (Internasional Space Station). Meskipun dia tidak sedang berada di Bumi, dia tetap melakukan ibadah shalat.

\section{Identifikasi Arah Kiblat di Planet Mars}

Sebagaimana yang telah kita ketahui bahwa pada dasarnya, shalat haruslah dilakukan dengan menghadap kiblat, yakni Ka'bah. Dalam surat Al-Baqarah ayat 144 Allah berfirman :

$$
\begin{aligned}
& \text { قد نرى تقلب وجهاك فى السماء فلنولينك قبلة ترضها فول وجهاك شطر المسجد الحر ام وحيث ما كنتم فولوا }
\end{aligned}
$$

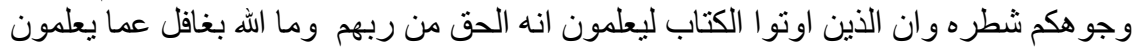

Dalam suatu hadist yang diriwayatkan oleh Malik juga disebutkan :

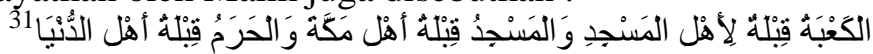
(Ka'bah adalah kiblatnya orang yang berada di Masjidil Haram. Masjidil Haram adalah kiblatnya orang yang berada di Makkah. Tanah Haram (Makkah) adalah kiblatnya orang sedunia)

Dalam hadist lainnya yang diriwayatkan oleh Imam Baihaqi dalam kitab sunannya disebutkan :

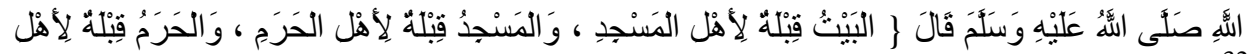

$$
{ }^{32}\{
$$

(Sesungguhnya Rasulullah SAW bersabda : Baitullah (Ka'bah) adalah kiblatnya orang yang berada di Masjidil Haram. Masjidil Haram adalah kiblatnya orang yang berada di Makkah. Tanah Haram (Makkah) adalah kiblatnya orang di Bumi)

Ini berarti bahwa kiblat bagi orang yang berada di tempat tertentu adalah Ka'bah atau wilayah yang melingkupi ka'bah. Jadi, mafhum muwafaqoh-nya adalah kiblat bagi orang yang berada di planet Mars adalah wilayah yang melingkupi Ka'bah dilihat dari planet Mars yakni Bumi atau proyeksi arah Bumi jikalau Bumi tidak tampak.

Dan dengan mengingat perkembangan ilmu pengetahuan yang sedemikian hingga, tidak ada beban (masyaqqoh) yang berarti ketika dituntut untuk menghadap ke kiblat saat akan melaksanakan shalat di planet Mars. Dan kompleksifitas perhitungan juga bisa disederhanakan dengan memanfaatkan program microsft excel atau kalkulator. Adapun langkah-langkah yang harus ditempuh dalam perhitungannya yaitu :

\footnotetext{
${ }^{30}$ Zein Bin Ibrahim Bin Zein Bin Smith, ibid.

${ }^{31}$ Al-Qarafi, Anwarul Baruq, Maktabah Syamilah, Juz. 4, hal.75

${ }^{32}$ Ibid, hal. 76
} 
1. Menentukan waktu pengukuran dan koordinat geografis tempat yang akan diukur arah kiblatnya

2. Mencari Nilai Bujur Ekliptika (Ecliptic Longitude) planet Mars

3. Mencari Nilai Lintang Ekliptika (Ecliptic Latitude) planet Mars

4. Mencari Nilai Jarak (Distance) planet Mars ke Matahari

5. Mencari Nilai Bujur Ekliptika (Ecliptic Longitude) Heliosentris planet Bumi

6. Mencari Nilai Lintang Ekliptika (Ecliptic Latitude) Heliosentris planet Bumi

7. Mencari Nilai Jarak (Distance) planet Bumi ke Matahari

8. Mencari Nilai Julian Date, bilangan abad julian dan bilangan milenium julian

9. Mencari Nilai Jarak Bumi ke Mars

10. Mencari Nilai Asensiorekta Bumi dari Mars

11. Mencari Nilai Deklinasi Bumi dari Mars

12. Mencari nilai sudut elongasi bumi -Matahari

13. Mencari Nilai Fraksi Iluminasi Bumi

14. Mencari Nilai Semidiameter Bumi dari Mars

15. Mencari Nilai Lebar Piringan Bumi dari Mars

16. Mencari Nilai Koordinat Areosentrik Bumi yang meliputi bujur areosentrik, lintang areosentrik

17. Mencari Nilai Equation of time, dan nantinya akan ditemukan

18. Nilai Azimuth dan Altitude Bumi

\section{E. Penutup}

Dari pemaparan yang sudah diungkapkan dalam bab-bab sebelumnya, dapat disimpulkan bahwa :

1. Orang yang berada di planet Mars masih dikenai kewajiban untuk melakukan ibadah shalat

2. Arah Kiblat bagi orang yang berada di planet Mars adalah arah dimana bumi berada, karena di bumilah letak ka'bah atau garis proyeksi arah bumi.

3. Cara untuk mengetahui arah kiblat di planet Mars yaitu dengan mengetahui arah atau azimuth bumi dari planet Mars. Terlebih dahulu, harus ditentukan waktu pengukuran dan koordinat geografis tempat di Mars yang akan diukur arah kiblatnya. Selanjutnya harus diperhitungkan nilai koordinat ekliptika planet Mars, Bumi, nilai koordinat Areosentrik Bumi, termasuk juga nilai jarak Bumi ke Mars, nilai asensiorekta Bumi dari Mars, nilai deklinasi Bumi dari Mars, nilai sudut elongasi bumi -Matahari, nilai Fraksi Iluminasi Bumi, Nilai semidiameter Bumi dari Mars, nilai lebar piringan Bumi dari Mars, nilai equation of time, nilai azimuth dan altitude Bumi, nilai dan azimuth Matahari. Dari situ akan ditemukan dimana posisi Bumi dilihat dari Mars.[] 


\section{Daftar Pustaka}

Al-Qarafi, Anwarul Baruq, Maktabah Syamilah, Juz. 4

Ar-Ra'ini, Muhammad bin Muhammad bin Muhammad bin 'Abdur Rahman, Mawahib Al-Jalil, Daru 'Alim al-Kutub, 2003, juz. 2

Artikel Richard S. Young berjudul Kehidupan di Dunia Lain dalam buku Ilmu Pengetahuan Populer

Kementrian Agama RI, Tafsir Ilmi Penciptaan Jagad Raya Dalam Prespektif AlQur'an dan Sains, Jakarta : PT. Sinergi Pustaka Indonesia, 2012

Smith, Zein Bin Ibrahim Bin Zein Bin, At-Taqiratus Sadidah Fi Masail al-Mufidah, Surabaya : Darul 'Ulum al-Islamiyyah, 2006

Qasim, Syeikh Muhammad Bin, Fathul Qarib, Surabaya : Nurull Huda, tt

Yahya, Harun, Pesona Di Angkasa Raya, e-book.

http://www.astronomi.us/2013/05/lebih-dari-78-ribu-orang-mendaftar.html

http://www.merdeka.com/teknologi/200-ribu-orang-siap-jadi-warga-planet-mars.html

http://www.astronomi.us/2013/08/bukti-paling-nyata-air-pernah-ada-di.html

http://www.astronomi.us/2012/09/curiosity-temukan-batuan-yang-buktikan.html 


\title{
Sistem Hisab Awal Bulan Kamariah Dr. Ing. Khafid dalam Program Mawaiqt
}

\author{
Eni Nuraeni Maryam \\ eninuraenimaryam@gmail.com
}

\begin{abstract}
Abstrak
Perbedaan hari raya yang kerap terjadi di Indonesia membawa hikmah tersendiri bagi perkembangan ilmu falak. Di samping karena adanya perbedaan sikap terhadap laporan hasil rukyat pada saat itu, disebabkan pula oleh adanya perbedaan hasil hisab yang berkembang di Indonesia. Oleh sebab itulah orang-orang yang berkecimpung dalam dunia astronomi mulai menaruh perhatiannya terhadap perhitungan-perhitungan ilmu falak, khususnya perhitungan awal bulan Qamariah. Dalam kesempatan ini muncul program-program software yang menyiapkan data sekaligus melakukan perhitungan, sehingga program ini dirasa lebih praktis dan lebih udah bagi pemakainya. Program-program itu diantaranya "Falakiyah Najmi'oleh Nuril Fuad pada tahun 1995, program "Badiatul Misal'tahun 2000 dan program "Ahillah'tahun 2004 oleh Muhyiddin Khazin, program "Mawâqit Versi 2001" oleh Khafid pada tahun 2001. Mayoritas program diciptakan oleh para ahli astronomi maupun falak. Akan tetapi program "Mawâqit" diciptakan oleh Dr. Ing. Khafid dengan background keilmuannya yang merupakan seorang ahli geodesi. Lalu bagaimana implementasi pemikiran Dr. Ing. Khafid mengenai penentuan awal bulan Qamariah yang dituangkan dalam sebuah program yang bernama "Mawâqit".

Kata Kunci : Awal Bulan kamariah, Mawâqit, Dr. Ing. Khafid
\end{abstract}

\section{A. Pendahuluan}

Penentuan awal bulan Qamariah sangat penting artinya bagi segenap kaum muslimin, sebab banyak ibadah dalam Islam yang pelaksanaannya dikaitkan dengan perhitungan bulan Qamariah. Di antara ibadah-ibadah itu adalah shalat Idul Adha dan Idul Fitri, shalat gerhana bulan dan matahari, puasa Ramadhan dengan zakat fitrahnya, haji dan sebagainya. Demikian pula hari-hari besar dalam Islam, semuanya diperhitungkan menurut perhitungan bulan Qamariah. ${ }^{33}$

Sebenarnya, secara teknis ilmiah, posisi dan gerakan benda-benda langit sudah dapat dihitung, yaitu dengan ilmu astronomi modern dan bantuan komputer yang sangat teliti. Jangankan penampakan hilal yang sangat biasa dan selalu terjadi setiap bulan, perhitungan gerhana bulan maupun matahari yang relatif jarang pun bisa diperkirakan melalui perhitungan yang sangat teliti. Bahkan, soal yang jauh lebih rumit, seperti peristiwa langka berupa penampakan komet $^{34}$ yang terjadi setiap puluhan tahun bahkan ratusan tahun sekali, bisa diperhitungkan dengan baik. ${ }^{35}$

33 Badan Hisab dan Rukyat Departemen Agama, Almanak Hisab Rukyat, Jakarta: Proyek Pembinaan Badan Peradilan Agama Islam, 1981, h. 98.

${ }^{34}$ Komet adalah anggota tata surya yang berwujud gas dan menarik pandangan jika kebetulan ada di dekat matahari. Lintasan komet mengelilingi matahari berbentuk lonjong. Makin dekat dengan matahari makin menonjol ekornya, yang tak lain adalah gas mengembang. Lihat Iratius Radiman, dkk, Ensiklopedi Singkat Astronomi dan Ilmu Yang Bertautan, Bandung: Penerbit ITB, 1980, h. 50.

${ }^{35}$ Farid Ruskanda, 100 Masalah HIsab dan Rukyat Telaah Syariah, Sains, dan Teknologi, Jakarta: Gema Insani Press, 1996, h. 33. 
Dewasa ini metode hisab telah menggunakan komputer dengan tingkat presisi $^{36}$ yang jauh lebih tinggi dan akurat. Berbagai perangkat lunak (software) yang praktis juga telah ada. ${ }^{37}$ Bahkan dengan banyaknya program komputer, siapapun yang bisa mengoperasikannya, dengan mudah dapat menghitung posisi bulan dan matahari. Masalahnya, tidak semua orang mengerti arti angka dalam penentuan awal bulan Qamariah, khususnya dalam penentuan awal Ramadhan, Idul Fitri dan Idul Adha.

Kini, dengan metode astronomi yang sama, bahkan dengan program komputer, hasil hitungan pasti akan sama. Tidak peduli siapa yang menghitung, apakah Muhammadiyah, NU, Persis, atau orang awam. Terlalu naïf, ada yang merasa hasil hisab-nya lebih unggul dan seolah metodenya beda dengan metode ormas lain yang menggunakan rukyat. Padahal tidak ada bedanya, semua ormas bisa menghitung dengan hasil yang sama.

Dengan kemajuan teknologi yang didukung perangkat komputer modern, hasil hisab/rukyat yang dilakukan umat Islam dari belahan bumi lain dapat diketahui dengan cepat atau bahkan dalam hitungan milidetik oleh umat Islam di belahan bumi lainnya.

Diantara program-program komputer berbasis astronomi modern yang mendukung penentuan awal bulan Qamariah adalah Jean Meeus, Almanac Nautica, Astronomical Almanac, Mawâqit, Ascript, Astro Info, Starrynight, dan banyak software-software lainnya. Sistem hisab dalam program-program tersebut memiliki tingkat ketelitian yang tinggi sehingga dikelompokkan ke dalam High Accuracy Algorithm.

Di antara kesekian pemrograman komputer berbasis astronomi modern yang mendukung penentuan awal bulan Qamariah tersebut, penulis akan mengkaji Program Mawâqit yang merupakan implementasi dari hasil pemikiran Dr. Ing. Khafid.

Dr. Ing. Khafid adalah seorang ahli geodesi ${ }^{38}$ yang bekerja di Pusat Pemetaan Dasar Kelautan dan Kedirgantaraan Badan Koordinasi Survey dan Pemetaan Nasioanl (Bakosurtanal) ${ }^{39}$ Cibinong Bogor.

Para ahli astronomi menyatakan bahwa bentuk bumi adalah bulat. Hal tersebut terlihat dari rumus segitiga bola yang digunakan dalam penentuan awal bulan Qamariah. Sedangkan menurut ilmu geodesi, bentuk bumi tidaklah bulat pepat akan tetapi ellips (geoid).

Dengan background keilmuan Dr. Ing. Khafid yang bukan astronomi maupun ilmu falak melainkan geodesi, penulis ingin menelusuri salah satu software aplikasi falak yang terdapat dalam program Mawâqit khususnya mengenai sistem hisab awal bulan Qamariah.

\section{B. Biografi Intelektual Dr. Ing. Khafid}

Khafid, lahir di Demak, 4 Maret 1967. Sebagian besar masa kecilnya dihabiskan di Demak. Sekolah di SDN Kadilangu I Demak, SMP Negeri II Demak,

\footnotetext{
${ }^{36}$ Presisi adalah ketelitian. Lihat Pius A. Partanto dan M. Dahlan Al Barry, Kamus Ilmiah Populer, Surabaya: Arkola, 1994, h. 623.

${ }^{37}$ Encup Supriatna, Hisab Rukyah dan Aplikasinya (Buku Satu), Bandung: Refika Aditama, Cet. Ke-1, 20017, h. 1.

38 Geodesi merupakan ilmu mengenai ukuran dan bentuk bumi serta metode untuk mengetahui ukurannya. Lihat Iratius Radiman, dkk, Ensiklopedi Singkat Astronomi dan Ilmu Yang Bertautan, h. 35 .

${ }^{39}$ Sekarang Bakosurtanal berganti nama menjadi Badan Informasi Geospasial (BIG).
} 
dan SMA Negeri I Demak. Khafid baru meninggalkan Demak pada tahun 1987 setelah menerima beasiswa OFP (Offersis Felope Program) yang disponsori oleh BJ. Habibi. Khafid merupakan satu dari 250 penerima beasiswa tersebut yang dikirim ke berbagai Negara seperti Perancis, Jerman, Belanda, Amerika, Jepang, Austria dan Negara lainnya yang kemudian akan ditempatkan di beberapa lembaga, diantaranya LIPI (Lembaga Ilmu Pengetahuan Indonesia), Badan Meteorologi dan Fisika (BMKG), Badan Informasi Geospasial (BIF), Badan Pengkajian dan Penerapan Teknologi (BPPT), Lembaga Penerbangan Antariksa Nasional (LAPAN), dan lembaga lainnya.

Sesuai dengan minatnya kepada teknik informatik, Khafid memilih jurusan Teknik Informatika ke Jepang, akan tetapi nasib berkata lain. Khafid mendapatkan jatah beasiswa ke Belanda dengan jurusan Teknik Geodesi sesuai dengan penempatannya nanti di Bakosurtanal (sekarang BIG). Karena pada awalnya Khafid memang berkeinginan untuk mempelajari teknik informatika, meskipun sekolah jurusan teknik geodesi tetapi dia senang mengotak-atik komputer yang pada akhirnya menghasilkan macam-macam software, salah satu diantaranya Mawâqit.

Lulus SMA (1987) dia kemudian melanjutkan program S1 di Teknik Geodesi Universitas Delft Belanda. Karena program S1 dan S2-nya merupakan satu paket, program S2 pun ditempuhnya di Universitas yang sama. Program sarjana dan magisternya diselesaikan dalam kurun waktu 6,5 tahun. Kemudian Khafid melanjutkan program Doktornya di Universitas Teknik Munchen Jerman. ${ }^{40}$

Bersamaan dengan masuknya Khafid menjadi anggota Badan Hisab Rukyat Pusat pada tahun 2001, disanalah program Mawâqit mulai dikenal. Tahun 2006 Khafid dimintai kesediaannya oleh Rois PBNU, KH. Ghozali Masruri, untuk menjadi anggota Litbang LF-PBNU.

Saat ini Khafid bekerja di Badan Informasi Geospasial (BIG). Selain menjadi anggota Badan Hisab Rukyat nasional mewakili BIG, dia juga menjadi salah satu tim penyusun Sub Misi Landas Kontinental Indonesia yang dikirim ke PBB. Hal ini terkait dengan batas wilayah Indonesia yang dimungkinkan untuk diperluas, dimana dia harus membuktikan data-datanya dengan menyusun data taktis untuk dikirim ke $\mathrm{PBB}^{41}$

\section{Karya-karya Dr. Ing. Khafid}

Mawâqit merupakan salah satu software karya Khafid yang berasal dari kegemarannya terhadap teknik informatika dan keinginan untuk menyatukan perbedaan penentuan awal bulan Qamariah yang terjadi di sekelilingnya, khususnya di antara teman-temannya yang berasal dari berbagai Negara, seperti Maroko, Mesir Suriname, Turki, dan Negara lainnya. Berdasarkan perbedaan tersebut, Khafid merasa tertarik untuk mempelajari ilmu falak. ${ }^{42}$ Dengan keahliannya di bidang teknik informatika, Khafid dkk berhasil menciptakan software penentuan awal bulan Qamariah yang diberi nama Mawâqit 1.0.

Ketika duduk di bangku kuliah, dia lebih banyak mempelajari Teknik Satelit Altimetri (mengukur permukaan air laut dari satelit) untuk memprediksi gunung bawah laut, kedalaman laut, naik turunnya air laut, dan sebagainya. Sesuai dengan jurusannya tersebut, dia menghasilkan software pemrosesan data altimetri, software 28 Juli 2010.

${ }^{40}$ Wawancara dengan Dr. Ing. Khafid di Hotel Nalendra Cihampelas Bandung pada tanggal

${ }^{41}$ Wawancara dengan Dr. Ing. Khafid via Email pada 12 Oktober 2010.

${ }^{42}$ Wawancara dengan Dr. Ing. Khafid di Kantor Pascasarjana UIN Walisongo Semarang pada 8 Mei 2010 . 
untuk menghitung geoid, dan software-software lainnya. Mawâqit adalah satusatunya software hisab rukyat karyanya. Diantara semua software buatannya, software yang cukup besar adalah Mawâqit dan software Pemrosesan Data Altimetri.

Karya lain yang berbentuk buku adalah buku formal (tidak diperjualbelikan di pasaran melainkan untuk dikirimkan ke PBB), di antaranya adalah buku laporan survey. Adapun buku hisab rukyat karya Khafid hanya Buku Garis Tanggal Kalender Islam yang berisi tentang kalender Qamariah, garis tanggal Internasional, problematika penentuan awal bulan kalender Islam, penentuan awal bulan di Saudi Arabia, peran ilmu astro-geodesi dalam penanggalan Qamariah dan penelitian perhitungan penentuan awal bulan Qamariah. ${ }^{43}$

\section{Pemikiran Dr. Ing. Khafid tentang Hisab Awal Bulan Qamariah Program Mawaaqit}

Geodesi merupakan suatu cabang ilmu yang mempelajari ilmu ukur tanah (bumi). Sebagai seorang ahli geodesi, Khafid tidak mempelajari ilmu astronomi secara mendalam ketika di bangku kuliah. Hal ini dikarenakan di fakultas geodesi tidak ada mata kuliah yang mempelajari astronomi secara khusus, yang ada mata kuliah Geodetik Astronomi yang hanya mempelajari masalah positioning (tempat). Meskipun demikian, Khafid telah berhasil menciptakan sebuah program software) yang merupakan aplikasi dari ilmu falak, yaitu Mawâqit.

Perbedaan penentuan awal bulan Qamariah yang terjadi di antara Khafid dkk menjadi motivasi penyatuan penentuan awal bulan Qamariah di Belanda. Pada tahun 1992/1993 ICMI orsat Belanda mensponsori penelitian perhitungan awal bulan Qamariah dengan metode astronomi modern. Pelaksanaan kegiatan penelitian itu dilakukan oleh beberapa siswa yang sedang bertugas di Delft Belanda. Adapun peneliti-peneliti tersebut adalah Khafid, Wakhid Sudiantoro Putro, Dadan Ramdani, Ade Komara Mulyana, Adi Junjunan Mustafa (dari Bakosurtanal) dan Kiki Yaranusa (dari IPTN). ${ }^{44}$

Kegiatan penelitian ini menghasilkan software Mawaqit 1.0 yang ditulis dalam bahasa program PASCAL dalam DOS. Tanggapan positif dari kalangan masyarakat muslim Indonesia baik yang berada di mancanegara maupun yang ada di dalam negeri, bahkan banyaknya tanggapan dari masyarakat muslim dari Negara lain memberikan bukti bahwasanya penelitian lebih lanjut sangat diperlukan. Pada periode tahun 1994 sampai 1996, Khafid dan Fahmi Amhar dari Bakosurtanal melakukan perbaikan-perbaikan program Mawâqit sampai pada versi 1.3.

Bersamaan dengan perkembangan teknologi komputer, terutama didorong dengan munculnya sistem operasi baru Windows 95 dan Windows NT dan juga teknologi internet, peneltian lebih lanjut tentang perhitungan kalender Qamariah dilakukan oleh Khafid. Sebagai hasilnya dipublikasikan serangkaian versi software Mawâqit dan Mawâqit 32++ yang ditulis dengan bahasa program $\mathrm{C} / \mathrm{C}++$ berjalan dalam sistem operasi Windows 95/Windows NT, Mawâqit 96.04 versi internet ditulis dengan Java. Selanjutnya muncul Mawâqit 2000 yang sudah dilengkapi dengan modul-modul analisis yang diperlukan. Saat ini Mawâqit yang teraktual adalah versi 2001. 28 Juli 2010.

${ }^{43}$ Wawancara dengan Dr. Ing. Khafid di Hotel Nalendra Cihampelas Bandung pada tanggal

${ }^{44}$ Khafid, Petunjuk Pemakaian Program Mawaqit Versi 2001, Disampaikan pada Kuliah Umum dan Penutupan Kursus Hisab Rukyat Pengadilan Tinggi Agama Surabaya Tanggal 4-5 September 2005 dengan topik: Komputerisasi Program Hisab Rukyat. 
Dalam program penentuan awal bulannya, Khafid menggunakan teori algoritma dengan ketelitian yang sangat tinggi yaitu VSOP87. Variattions Seculaires des Orbites Planetaires Theory (VSOP) ini disusun oleh Bretagnon pada tahun 1982 dan disempurnakan oleh Bretagnon dan Francou pada tahun 1987 sehingga sering disebut VSOP87. ${ }^{45}$ Jean Meeus menyatakan bahwa dengan teori dan algoritma VSOP87 akurasi yang didapatkan adalah lebih baik dari 0.01 ". ${ }^{46}$

Pada Mawâqit versi 1.0 yang ditulis dalam bahasa program PASCAL dan DOS hingga Mawâqit versi 2000 Khafid menggunakan algoritma Meeus dengan kisaran ketelitian sekitar 1", akan tetapi pada Mawâqit versi 2001 Khafid mengkombinasikan algoritma Meeus dengan VSOP87 yang ketelitiannya mencapai 0.01 ”.

Khafid menggunakan teori dan algoritma VSOP87 untuk menetukan koordinat matahari yang meliputi lintang matahari, ${ }^{47}$ bujur matahari, ${ }^{48}$ jarak matahari dari bumi, deklinasi matahari, ${ }^{49}$ asensio rekta, ${ }^{50}$ tinggi matahari dari horizon, ${ }^{51}$ dan azimuth matahari. ${ }^{52}$

Sedangkan untuk menetukan posisi bulan, Khafid menggunakan algoritma Jean Meeus yang meliputi lintang bulan, bujur bulan, jarak bulan dari bumi, deklinasi bulan, asensio rekta, tinggi bulan dari horizon, dan azimuth bulan, umur bulan, fase illuminasi, ${ }^{53}$ elongasi. ${ }^{54}$

Algoritma Meeus sendiri sebenarnya merupakan reduksi dari algoritma VSOP87 yang lengkap. Dari ribuan suku koreksi dalam algoritma VSOP87, maka

${ }^{45}$ Dhani Herdiwijaya, Makalah disampaikan pada acara Diklat Nasional Pelaksana Rukyat Nahdatul Ulama, oleh Lajnah Falakiyah NU di Masjid Agung Jawa Tengah, 19 Desember 2006.

$46 \quad$ http://www.eramuslim.com/syariah/ilmu-hisab/posisi-matahari-algoritma-meeus.htm. Diakses pada 9 Desember 2010.

47 Lintang matahari/lintang ekliptika dikenal dalam bahasa Indonesia dengan lintang astronomi yang dikenal pula dengan 'ardlusy syams. Data ini adalah jarak titik pusat matahari dari lingkaran ekliptika. Lihat Direktorat Urusan Agama Islam dan Pembinaan Syariah Ditjen Bimbingan Masyarakat Islam, Ephemeris Hisab Rukyat, Departemen Agama RI, h. 3.

${ }^{48}$ Bujur matahari/ Bujur ekliptika dikenal dalam bahasa Indonesia dengan bujur astronomi yang dikenal pula dengan istilah Taqwim atau Thul yakni jarak matahari dari titik Aries (Vernal Equinox) diukur sepanjang lingkaran ekliptika. Ephemeris Hisab Rukyat, Departemen Agama RI, $h$. 3 .

49 Apparent Declination dikenal dalam bahasa Indonesia dengan deklinasi matahari yang terlihat (bukan matahari hakiki) atau yang dikenal dengan mail syams adalah jarak matahari dari equator. Ephemeris Hisab Rukyat, Departemen Agama RI, h. 3.

${ }^{50}$ Apparent Right Ascension dikenal dalam bahasa Indonesia dengan Asensio Rekta. Data ini adalah jarak matahari dari titik Aries diukur sepanjang lingkaran equator. Ephemeris Hisab Rukyat, Departemen Agama RI, h. 3.

${ }^{51}$ Ketinggian yang dalam astronomi dikenal dengan istilah altitude, yaitu ketinggian benda langit dihitung sepanjang lingkaran vertikal dari ufuk sampai benda langit yang dimaksud. Ketinggian benda langit bertanda positif (+) apabila benda langit ybs berada di atas ufuk, demikian pula bertanda negatif (-) apabila ia berada di bawah ufuk. Dalam astronomi biasanya diberi notasi $h$ (hight). Lihat Muhyiddin Khazin, Kamus Ilmu Falak, Jogjakarta: Buana Pustaka, Cet. Ke-1, 2005, h. 37.

${ }^{52}$ Azimuth matahari adalah busur matahari pada lingkaran horizon diukur mulai dari titik utara ke arah timur atau kadang-kadang diukur dari titik selatan ke arah barat. Dalam bahasa Arab disebut as-simt. Lihat Encup Supriatna, Hisab Rukyat dan Aplikasinya, Bandung: Refika Aditama, 2007, h. $x i$

${ }^{53}$ Iluminasi adalah luas bagian bulan yang memancarkan sinar, dalam praktek perhitungan, harga maksimal iluminasi bulan adalah 1 (satu) yakni ketika terjadi bulan purnama. Lihat Muhyiddin Khazin, Kamus Ilmu Falak, h. 34.

${ }^{54}$ Elongasi adalah sudut pada bumi yang dibentuk oleh garis hubung antara suatu planet dengan bumi. Elongasi $0^{\circ}$ ketika terjadi konjungsi; $90^{\circ}$ ketika pada kwartir pertama, $180^{\circ}$ ketika oposisi, dan $270^{\circ}$ ketika pada kwartir kedua. Lihat Muhyiddin Khazin, Kamus Ilmu Falak, h. 23. 
yang diperhitungkan adalah sekitar ratusan suku-suku yang besar dan penting dalam algoritma Meeus ini. ${ }^{55}$

\section{E. Penentuan Awal Bulan Menurut Kriteria Astro-Geodesi}

Untuk memprediksi visibilitas hilal, hal pokok yang harus diketahui adalah posisi bulan dan matahari terhadap bumi. Untuk itu setidaknya harus dipertimbangkan faktor-faktor astro-geodesi sebagai berikut: ${ }^{56}$

1. Konjungsi

Sebagai syarat mutlak nampaknya hilal adalah terjadinya ijtima'. Ijtima' artinya berkumpul atau bersama, yaitu posisi Matahari dan Bulan berada pada satu bujur astronomi. Dalam stronomi dikenal dengan istilah Conjunction (konjungsi). Para ahli astronomi murni menggunakan ijtima' ini sebagai kriteria pergantian bulan Qamariah, sehingga ia disebut pula dengan New Moon (bulan baru). ${ }^{57}$

Bulan baru dalam astronomi tidaklah sama dengan definisi bulan baru dalam kalender Qamariah. Bulan baru dalam astronomi adalah konjungsi yang terjadi serentak untuk seluruh dunia, akan tetapi belum tentu pada saat tersebut bulan dapat terlihat dengan mata. Sedangkan bulan baru dalam kalender Islam disebut dengan awal bulan Qamariah, tergantung pada kenyataan kenampakan bulan (hilal) pertama kali dari pengamat yang berada di bumi setelah terjadinya konjungsi. Kenampakan bulan sudah barang tentu tergantung juga pada lokasi atau posisi dimana pengamat berada di muka bumi. Hal inilah diantaranya yang dapat menyebabkan terjadinya perbedaan prediksi teramatinya hilal. Perbedaan atau selisih waktu tersebut dapat menyebabkan beda penanggalan satu hari.

Secara perhitungan astro-geodesi modern kapan terjadinya konjungsi dapat diperkirakan dengan ketelitian sampai beberapa detik. Contoh yang jelas adalah prakiraan terjadinya gerhana bulan atau gerhana matahari yang dapat dilakukan dengan ketelitian sampai bilangan beberapa detik.

\section{Peta Ketinggian Bulan}

Pada dasarnya dengan ilmu astro-geodesi, ketinggian bulan atau hilal dapat diperkirakan untuk berbagai tempat di seluruh belahan bumi. Adanya perhitungan yang akurat dan penyajian yang gamblang dalam bentuk peta akan sangat membantu analisis untuk keperluan prediksi kenampakan bulan. Peta semacam ini perlu dibuat di hari saat yang diduga hilal akan nampak. Di dalam peta, bisa kita lihat adakalanya satu wilayah mempunyai ketinggian bulan positif dan adakalanya negatif. Wilayahwilayah yang mempunyai ketinggian bulan negatif sudah barang tentu dapat disimpulkan di wilayah tersebut tidaklah mungkin bulan akan nampak. Sedangkan untuk daerah-daerah yang mempunyai ketinggian positif masih perlu dianalisis lebih lanjut dengan gabungan data-data lainnya. ${ }^{58}$

\section{Peta Ketinggian Matahari}

Kenampakan bulan dari pengamat yang berada di bumi sangat dipengaruhi oleh sinar matahari. Di samping itu di saat-saat terjadinya hilal dimana intensitas

${ }^{55}$ Dhani Herdiwijaya, Makalah disampaikan pada acara Diklat Nasional Pelaksana Rukyat Nahdatul Ulama, oleh Lajnah Falakiyah NU di Masjid Agung Jawa Tengah, 19 Desember 2006.

${ }^{56}$ Khafid, Petunjuk Pemakaian Program Mawaqit Versi 2001

${ }^{57}$ Muhyiddin Khazin, 99 Tanya Jawab Masalah Hisab dan Rukyat, Yogyakarta: Ramadhan Press, 2009, h. 70.

${ }^{58}$ Khafid, Petunjuk Pemakaian Program Mawaqit Versi 2001, h. 18. 
pencahayaan bulan masih sangat rendah, cahaya matahari sangat berpengaruh dalam hasil pengamatan kenampakan bulan. Itulah sebabnya pengamatan kenampakan hilal harus dilakukan setelah matahari terbenam. Peta ketinggian matahari akan sangat membantu perhitungan kenampakan bulan dengan teliti. ${ }^{59}$

\section{Peta Umur Bulan Saat Matahari Terbenam}

Terjadinya konjungsi saja tidak memberikan jaminan bahwa hilal pasti Nampak. Syarat-syarat berikutnya yang harus dipenuhi adalah umur bulan ${ }^{60}$ saat matahari terbenam. Informasi tentang umur bulan pada saat matahari terbenam inipun dapat disajikan dalam bentuk peta sebagai bahan analisis kenampakan hilal. ${ }^{61}$

\section{Peta Fase Pencahayaan Bulan}

Syarat yang harus dipertimbangkan untuk memperkirakan kenampakan hilal adalah fase pencahayaan bulan. Bisa jadi karena bulan sudah cukup fase pencahayaannya di saat syarat-syarat lain masih belum memenuhi kriteria yang ditentukan, namun dalam kenyataannya hilal sudah nampak atau terjadi sebaliknya. Informasi tentang fase pencahayaan bulan yang tergantung tempat dan waktu ini bisa dipetakan juga untuk membantu analisis prakiraan kenampakan hilal.

\section{Peta Jarak Waktu Terbenam antara Matahari dan Bulan}

Rukyat harus dilakukan sesaat setelah matahari terbenam sampai bulan terbenam. Jadi tidak mungkin mengamati hilal apabila pada hari melakukan rukyat ternyata bulan terbenam mendahului matahari atau dalam artian bulan masih di bawah ufuk. Jarak waktu matahari dan bulan terbenam yang terlalu pendek pun mempunyai tingkat kenampakan hilal yang sangat kecil. Kenampakan hilal dapat dikaitkan dengan jarak waktu terbenam antara matahari dan bulan terbenam, "semakin lama jangka waktunya semakin besar kemungkinan hilal dapat diamati". Komponen inipun informasinya dapat dituangkan dalam bentuk peta, karena dari kenyataan bahwa jarak terbenam antara matahari dan bulan juga tergantung letak geografis suatu tempat.

\section{Overlay Antara Berbagai Topik Peta}

Dari berbagai faktor-faktor yang disebutkan di atas dapat dilakukan overlay ${ }^{62}$ peta sesuai dengan definisi kenampakan bulan menurut kriteria astro-geodesi.

\section{F. Sistem Hisab Awal Bulan Qamariah Dr. Ing. Khafid dalam Program Mawâqit}

Mawâqit merupakan salah satu contoh program komputer yang berbasis astronomi modern. Metode yang digunakan dalam penentuan awal bulan program Mawâqit adalah menggunakan metode Hisab Haqiqi Kontemporer. ${ }^{63}$ Dimana sistem

\footnotetext{
${ }^{59}$ Khafid, Petunjuk Pemakaian Program Mawaqit Versi 2001, h. 19.

${ }^{60}$ Umur Bulan didefinisikan sebagai hitungan waktu dengan epoch saat terjadinya konjungsi. Sebagai contoh: apabila hari ini terjadi konjungsi pada jam $15.00 \mathrm{WIB}$, dan matahari terbenam jam 18.00. Maka umur bulan saat matahari terbenam adalah 3 jam.

${ }^{61}$ Khafid, Petunjuk Pemakaian Program Mawaqit Versi 2001, h. 20.

${ }^{62}$ Overlay adalah lembaran penutup; lapisan atas; hamparan. Lihat John M. Echols dan Hasan Sadily, Kamus Inggris-Indonesia, Jakarta: Gramedia Pustaka Utama, Cet. Ke XXIV, 2000, h. 412.

${ }^{63}$ Yang termasuk klasifikasi Hisab Haqiqi Kontemporer adalah New Comb yang dipakai oleh Bidron Hadi, Almanac Nautika yang dikeluarkan oleh TNI AL Dinas Hidro Oseanografi Jakarta, The Astronomical Almanac yang diterbitkan Nautical Almanac Office, Astronomical Tables of Sun, Moon
} 
hisab ini menggunakan hasil penelitian terakhir dan menggunakan matematika yang telah dikembangkan.

Metodenya sama dengan metode Hisab Haqiqi Tahqiqi, ${ }^{64}$ hanya saja sistem koreksinya lebih teliti dan kompleks, sesuai dengan kemajuan sains dan teknologi. Rumus-rumusnya lebih disederhanakan sehingga untuk menghitungnya dapat digunakan kalkulator atau personal komputer. ${ }^{65}$

Mawâqit menggunakan metode astro-geodesi dalam penentuan awal bulan Qamariah-nya. Meskipun demikian rumus perhitungannya tetap menggunakan rumus astronomi (spherical trigonometry). Peran metode atro-geodesi adalah untuk memprediksi kenampakan bulan. Dengan kata lain, kapan hilal nampak dan dimana dapat diperhitungkan. ${ }^{66}$

Dalam perhitungannya ada beberapa koreksi terhadap ketinggian hilal, diantaranya:

a. Berbeda dalam melihat parallax/ikhtilaf al-mandzar.

Dengan koreksi ini berarti tinggi hilal diperhitungkan dari permukaan bumi tempat pengamat, bukan dari titik pusat bumi. Parallaks ini diformulasikan dengan besarnya suatu sudut antara dua garis yang ditarik dari benda langit ke titik pusat bumi dan garis yang ditarik dari benda langit ybs ke mata peninjau di permukaan bumi. Semakin jauh jaraknya semakin kecil harga parallaksnya. Begitu pula semakin tinggi posisi benda langit dari ufuk semakin kecil pula harga parallaksnya. ${ }^{67}$

b. Pembiasan Sinar (Refraksi)

Refraksi yaitu perbedaan antara tinggi suatu benda langit yang sebenarnya dengan tinggi benda langit itu yang dilihat sebagai akibat adanya pembiasan sinar. Refraksi terjadi karena sinar yang datang sampai ke mata kita telah melalui lapisan-lapisan atmosfer, sehingga sinar yang datang itu mengalami pembengkokan, padahal yang kita lihat adalah arah lurus pada sinar yang ditangkap mata kita. ${ }^{68}$

Dengan koreksi ini yang dihisab adalah tinggi melihat hilal, bukan tinggi nyata. Pada Mawâqit koreksi refraksi hanya diterapkan ketika matahari berada di atas ufuk. Jika hilal di bawah ufuk refraksi tidak diperhitungkan. Adapun refraksi di sekitar ufuk sebesar $0^{\circ} 34^{\prime}$.

Ketinggian hilal pada Mawâqit dihitung dari titik pusat bulan, sehingga semidiameter bulan tidak diperhitungkan. Begitupun dengan kerendahan ufuk tidak diperhitungkan, karena dalam Mawâqit ketinggian seluruh tempat dianggap $0 .{ }^{69}$

and Planets oleh Jean Meeus Belgia, Islamic Calender oleh Muhammad Ilyas dan Ephemeris oleh Badan Hisab Rukyah Depag. Lihat Sriyatin Shadiq, Perkembangan Hisab Rukyah dan Penetapan Awal Bulan Qamariah, dalam Muamal Hamidy (Editor), Menuju Kesatuan Hari Raya, Surabaya: Bina Ilmu, 1995, h. 67-68.

64 Yang termasuk klasifikasi Hisab Hakiky Tahqiqi adalah al-Mathla'us Said fi Hisabil Kawakib al Rusydil Jadid karya Syeh Husain Zaid al-Misra, Al-Manahijul Hamidiyah karya Syeh Abdul Hamid Mursy Ghaisul Falaky, Muntaha Nataijul Aqwal karya Muhammad Hasan Asy'ari, AlKhulasatul Wafiyah karya Zubaer Umar al-Jaelany, Badi'atul Mitsal karya Muhammad Ma'shum bin Ali, Hisab Haqiqi karya Muhammad Wardan DIpaningrat, Nurul anwar karya Noor Ahmad Shadiq bin Saryani, ittifaq Dzatil Bain karya Muhammad Zubaer Abdul Karim, lihat Sriyatin Shadiq, Perkembangan Hisab Rukyah dan Penetapan Awal Bulan Qamariah, dalam Muamal Hamidy (Editor), Menuju Kesatuan Hari Raya, h. 67.

65 Ahmad Izzuddin, Fiqh Hisab Rukyah, Menyatukan NU dan Muhammadiyah dalam Penentuan Awal Ramadhan, Idul Fitri dan Idul Adha, Jakarta: Erlangga, 2007, h. 8.

${ }^{66}$ Khafid, Garis Tanggal Kalender Islam 1427 H, Cibinong: Badan Koordinasi Survey dan Pemetaan Nasional, 2006, h. 17.

${ }^{67}$ Muhyiddin Khazin, Ilmu Falak dalam Teori dan Praktek, Yogyakarta: Buana Pustaka, Cet. Ke-1, 2004, h. 138.

${ }^{68}$ Muhyiddin Khazin, Ilmu Falak dalam Teori dan Praktek, h. 142.

${ }^{69}$ Wawancara dengan Dr. Ing. Khafid di Hotel Nalendra Cihampelas Bandung pada tanggal 28 Juli 2010. 


\section{G. Tingkat Akurasi Hisab Awal Bulan Qamariah dalam Program Mawâqit}

Dalam program penentuan awal bulannya, Khafid menggunakan sumber data dan algoritma dengan ketelitian yang sangat tinggi, yaitu VSOP87. Melihat dari teori dan algoritma yang digunakan dengan ketelitian lebih baik dari 0.01", hisab awal bulan Qamariah Program Mawâqit dapat dikatakan cukup akurat.

Di samping itu bukti keakurasiannya dapat dilihat dari hasil hisab Program Mawâqit ketika dibandingkan dengan hasil hisab Ephemeris yang termasuk ke dalam High Accuracy Algorithm yang selama ini sering dijadikan pedoman pelaksanaan rukyat dalam penentuan awal bulan Qamariah.

Pada awalnya data yang dipakai oleh para astronom dalam perhitungan awal bulan Qamariah di Indonesia adalah data Almanac Nautika. Mengingat data Almanac Nautika itu hanya diterbitkan setiap tahun, sehingga apabila ingin melakukan perhitungan untuk dua tahun yang akan datang tentu mengalami kesulitan, sebab Almanac Nautica belum ada karena memang belum dikirim.

Ephemeris yang dikenal dengan "Hisab for Windows ver 1.0" merupakan salah satu program software data astronomis yang disusun pada tahun 1993 oleh Drs. Taufik beserta putranya atas biaya Departemen Agama RI. Software ini dibuat karena langkah perhitungan ilmu falak sampai periode ini dirasa panjang dan melelahkan, juga buku Almanak Nautika sering terlambat datang. Software ini hasilnya mirip dengan Almanak Nautika atau semacamnya. Kemudian pada tahun 1998, program ini disempurnakan dan berganti nama menjadi “Winhisab Versi 2.0" dengan hak lisensi pada Badan Hisab Rukyat Departemen Agama RI. Di antara isi program ini adalah data astronomis (Ephemeris) matahari dan bulan untuk keperluan perhitungan pengukuran arah kiblat, waktu-waktu shalat, awal bulan dan gerhana. Perhitungan yang menggunakan data dari program Winhisab ini dikenal juga dengan Sistem Ephemeris atau Sistem Ephemeris Hisab Rukyat. ${ }^{70}$

Berikut data hasil hisab Program Mawâqit dan Ephemeris Hisab Rukyat dalam penentuan awal bulan Ramadhan $1431 \mathrm{H}$ untuk Markaz Semarang dengan koordinat $6^{\circ} 58^{\prime} \mathrm{LS}$ dan $110^{\circ} 29^{\prime}$ BT dengan ketinggian $0 \mathrm{~m}$.

\begin{tabular}{|c|c|c|}
\hline \multirow[b]{2}{*}{ Hasil Hisab } & \multicolumn{2}{|c|}{ Sistem } \\
\hline & Ephemeris Hisab Rukyat & Mawâait \\
\hline Ijtima’ & $\begin{array}{l}\text { Selasa, 10 Agustus } 2010 \\
\text { Pukul. 10:09:17 }\end{array}$ & $\begin{array}{l}\text { Selasa, 10 Agustus } 2010 \\
\text { Pukul. 10:08:01 }\end{array}$ \\
\hline Matahari terbenam & 17. 39. 09.33 WIB & 17. 39. $09 \mathrm{WIB}$ \\
\hline Azimuth matahari & $285^{\circ} 32^{\prime} 20.00^{\prime \prime}$ & $285^{\circ} 32^{\prime} 19.00^{\prime \prime}$ \\
\hline Azimuth bulan & $281^{\circ} 23^{\prime} 03.70^{\prime \prime}$ & $281^{\circ} 22^{\prime} 58.00^{\prime \prime}$ \\
\hline Posisi hilal & $04^{\circ} 09^{\prime} 16.38^{\prime \prime} \mathrm{SM}$ & $04^{\circ} 09^{\prime} 20.38^{\prime \prime}$ \\
\hline Tinggi hilal & $02^{\circ} 06^{\prime} 27.03^{\prime \prime}$ & $02^{\circ} 07^{\prime} 06.89^{\prime \prime}$ \\
\hline
\end{tabular}

Ketidaksamaan hasil perhitungan itu terjadi mungkin karena:

1. Data koordinat (lintang dan bujur tempat observasi) yang digunakan tidak sama.

2. Koreksi-koreksi terhadap gerak bulan yang dimasukkan tidak sama.

3. Pangkal ukur perhitungan ketinggian hilal tidak sama. Ada yang menghitung ketinggian hilal dari ufuk haqiqi dan adapula yang menghitungnya dari ufuk mar'i.

4. Bagian hilal yang dihitung tidak sama. Ada yang menghitung ketinggian hilal dari ufuk sampai titik pusat hilal. Ada yang menghitung ketinggian hilal dari

${ }^{70}$ http://prisdaba.blogspot.com 
ufuk sampai piringan atas hilal dan ada yang menghitung ketinggian hilal dari ufuk sampai piringan bawah hilal. ${ }^{71}$

Secara keseluruhan rumus-rumus yang digunakan dalam perhitungan awal bulan Qamariah Program Mawâqit sama dengan rumus perhitungan yang digunakan Ephemeris Hisab Rukyat, hanya saja ada beberapa turunan rumus yang berbeda, di antaranya rumus menghitung azimuth, dan refraksi.

Di samping itu, koreksi terhadap ketinggian hilal pada Program Mawâqit hanya terdiri dari dua macam, yaitu koreksi refraksi dan parallaks, berbeda dengan koreksi pada sistem Ephemeris HIsab Rukyat yang juga memperhitungkan kerendahan ufuk/dip. Hal ini disebabkan karena pada Mawâqit ketinggian semua tempat dianggap 0.

Perbedaan lain pada Mawâqit dan Ephemeris Hisab Rukyat adalah sumber data Ephemeris yang digunakan dalam Mawâqit menggunakan jam LMT (Local Mean Time), sedangkan Ephemeris HIsab Rukyat menggunakan jam GMT (Greenwich Mean Time).

Kemudian terdapat perbedaan data koordinat Program Mawâqit dengan data koordinat dari sumber lain. Misalkan koordinat kota Semarang, pada Mawâqit dituliskan bahwa koordinat kota Semarang adalah $6^{\circ} 58^{\prime}$ LS dan $110^{\circ} 29^{\prime}$, sedangkan kebanyakan sumber lain menyatakan bahwa koordinat kota Semarang adalah $7^{\circ} 00^{\prime}$ LS dan $110^{\circ} 24^{\prime}$ BT. Perbedaan tersebut kemungkinan disebabkan oleh karena Program Mawâqit belum dikoreksi kembali setelah versi terakhirnya yang dikeluarkan pada tahun 2001.

Program Mawâqit dalam penentuan awal bulan Qamariah tentunya memiliki kelebihan dan kekurangan. Kelebihannya antara lain:

1. Penentuan awal bulan Qamariah Program Mawâqit yang bersifat opsional memudahkan semua golongan untuk menyesuaikan kriteria penentuan awal bulan yang dikehendakinya untuk mengetahui kapan awal bulan Qamariah dimulai sejak jauh-jauh hari, terutama bulan-bulan yang ada kaitannya dengan ibadah umat Islam.

2. Program Mawâqit dilengkapi dengan peta kenampakan hilal dan data koordinat kota-kota besar di seluruh dunia, sehingga akan memudahkan pengguna untuk mengetahui kapan dan dimana hilal akan terlihat.

3. Tingkat ketelitian data yang digunakan dalam program Mawâqit cukup tinggi. Dengan teori dan algoritma VSOP87 akurasi yang didapatkan adalah lebih baik dari 0.01". sehingga hasil hisab Program Mawâqit bisa menghasilkan data yang akurat dan dapat dijadikan pedoman penentuan awal bulan Qamariah.

Adapun kekurangannya antara lain:

1. Program Mawâqit belum mencantumkan ketinggian tempat dalam perhitungan awal bulan Qamariah, ketinggian semua tempat dianggap 0 padahal ketinggian bulan dipengaruhi juga oleh ketinggian tempat.

2. Data koordinat kota-kota yang terdapat pada Program Mawâqit adalah data lama yang belum diperbaharui lagi selama 10 tahun, sehingga data-data tersebut memerlukan koreksi dengan data-data koordinat yang terbaru.

\footnotetext{
${ }^{71}$ Muhyiddin Khazin, 99 Tanya Jawab Masalah Hisab dan Rukyat, h. 83.
} 


\section{H. Penutup}

Metode hisab awal bulan Qamariah Program Mawâqit adalah Hisab Haqiqi Kontemporer. Sistem hisab ini menggunkan hasil penelitian terakhir dan menggunakan metematika yang telah dikembangkan. Metodenya sama dengan metode Hisab Haqiqi Tahqiqi hanya saja sistem koreksinya lebih teliti dan kompleks, sesuai dengan kemajuan sains dan teknologi. Rumus-rumusnya lebih disederhanakan sehingga untuk menghitungnya dapat digunakan kalkulator atau personal komputer.

Mawâqit menggunakan metode astro-geodesi dalam penentuan awal bulan Qamariah. Kaitannya dalam penentuan awal bulan Qamariah, metode astro-geodesi digunakan untuk memprediksi kenampakan bulan. Dengan kata lain, kapan hilal nampak dan dimana dapat diperhitungkan.

Program Mawâqit sendiri merupakan software yang dirancang sebagai alat bantu untuk mempermudah hisab awal bulan Qamariah. Mawâqit sifatnya opsional, dapat digunakan oleh ormas manapun baik NU, Muhammadiyah, maupun Persis. Tidak ada kriteria khusus yang dipakai Mawâqit dalam penentuan awal bulan Qamariah. Dengan sifatnya yang opsional, Mawâqit bisa di-set untuk kriteria Danjon, MABIMS, Imkan al-Rukyat, ataupun Wujud al-Hilal. 


\section{Daftar Pustaka}

Badan Hisab dan Rukyat Departemen Agama, Almanak Hisab Rukyat, Jakarta: Proyek Pembinaan Badan Peradilan Agama Islam, 1981.

Direktorat Urusan Agama Islam dan Pembinaan Syariah Ditjen Bimbingan Masyarakat Islam, Ephemeris Hisab Rukyat, Departemen Agama RI.

Echols, John M., dan Hasan Sadily, Kamus Inggris-Indonesia, Jakarta: Gramedia Pustaka Utama, Cet. Ke XXIV, 2000.

Herdiwijaya, Dhani, Makalah disampaikan pada acara Diklat Nasional Pelaksana Rukyat Nahdatul Ulama, oleh Lajnah Falakiyah NU di Masjid Agung Jawa Tengah, 19 Desember 2006.

Izzuddin, Ahmad, Fiqh Hisab Rukyah, Menyatukan NU dan Muhammadiyah dalam Penentuan Awal Ramadhan, Idul Fitri dan Idul Adha, Jakarta: Erlangga, 2007.

Khafid, Petunjuk Pemakaian Program Mawaqit Versi 2001, Disampaikan pada Kuliah Umum dan Penutupan Kursus Hisab Rukyat Pengadilan Tinggi Agama Surabaya Tanggal 4-5 September 2005 dengan topik: Komputerisasi Program Hisab Rukyat.

, Garis Tanggal Kalender Islam 1427 H, Cibinong: Badan Koordinasi Survey dan Pemetaan Nasional, 2006.

Khazin, Muhyiddin, Ilmu Falak dalam Teori dan Praktek, Yogyakarta: Buana Pustaka, Cet. Ke-1, 2004.

2005. , Muhyiddin, Kamus Ilmu Falak, Jogjakarta: Buana Pustaka, Cet. Ke-1, Ramadhan Press, 2009.

Muhyiddin, 99 Tanya Jawab Masalah Hisab dan Rukyat, Yogyakarta:

Partanto, Pius A., dan M. Dahlan Al Barry, Kamus Ilmiah Populer, Surabaya: Arkola, 1994.

Radiman, Iratius, dkk, Ensiklopedi Singkat Astronomi dan Ilmu Yang Bertautan, Bandung: Penerbit ITB, 1980.

Ruskanda, Farid, 100 Masalah HIsab dan Rukyat Telaah Syariah, Sains, dan Teknologi, Jakarta: Gema Insani Press, 1996.

Shadiq, Sriyatin, Perkembangan Hisab Rukyah dan Penetapan Awal Bulan Qamariah, dalam Muamal Hamidy (Editor), Menuju Kesatuan Hari Raya, Surabaya: Bina Ilmu, 1995.

Supriatna, Encup, Hisab Rukyah dan Aplikasinya (Buku Satu), Bandung: Refika Aditama, Cet. Ke-1, 2007.

Wawancara dengan Dr. Ing. Khafid di Kantor Pascasarjana UIN Walisongo Semarang pada 8 Mei 2010.

Wawancara dengan Dr. Ing. Khafid di Hotel Nalendra Cihampelas Bandung pada tanggal 28 Juli 2010.

Wawancara dengan Dr. Ing. Khafid via Email pada 12 Oktober 2010.

\section{Website}

http://www.eramuslim.com/syariah/ilmu-hisab/posisi-matahari-algoritmameeus.htm. Diakses pada 9 Desember 2010.

http://prisdaba.blogspot.com. Diakses pada 9 Desember 2010. 


\title{
Arah Kiblat di Planet Mars
}

\author{
M. Ikhtirozun Ni’am \\ ihtirozun_n@yahoo.co.id
}

\begin{abstract}
Abstrak
Dalam beberapa dekade akhir ini, upaya untuk mencari adanya kehidupan di luar Bumi gencar dilakukan. Planet Mars dalam hal ini menjadi sasaran utama untuk dideteksi adanya kemungkinan kehidupan di dalamnya. Karena planet Mars dianggap sebagai planet yang mirip dengan Bumi di bandingkan dengan planet-planet lain di tata surya. Mulai dari tahun 1962, ilmuwan mengirimkan pesawat ruang angkasa Mars-1 untuk mendeteksi adanya kehidupan di planet Mars.

Misi tersebut dilanjutkan dengan mengirimkan pesawat ruang angkasa Mars-2 pada tahun 1971 dan Mars-3 pada tahun 1972. Pada tahun 1965, dilanjutkan dengan penyelidikan Mariner 4. Dari Mariner 4 ini diperoleh foto-foto permukaan planet Mars untuk pertama kalinya. Misi lainnya yaitu dengan mengirimkan viking orbiters, viking experiment, phoenix lander pada tahun 2008 dan Misi Mars Science Laboratory dengan mengirimkan penjelajah Coriousity pada tanggal 26 November 2011. Ke depan, misi ini akan dilanjutkan dengan mengirimkan pesawat ruang angkasa Exo Mars, Penjelajah Mars 2020 (Mars Rover 2020) dan misi Mars One. Misi Mars One ini bertujuan untuk menciptakan koloni manusia di planet Mars. Jadi, manusia yang dikirimkan ke planet ini tidak akan dikembalikan lagi ke Bumi, melainkan akan menetap di planet Mars. Misi ini akan dimulai pada tahun 2023 dengan mengirimkan 4 peserta yang lolos seleksi dan dilanjutkan 2 peserta lainnya setiap 2 tahun sekali.

Sampai pada bulan Februari 2014, tercatat lebih dari 200.000 manusia yang sudah mendaftarkan diri untuk mengikuti perjalanan satu arah menuju Mars ini. Dan uniknya 500 diantaranya adalah orang Arab Saudi yang notabene beragama Islam. Sehingga muncul persoalan terkait pelaksanaan peribadatan yang pada biasanya terkait dengan fenomena yang ada di Bumi, seperti harusnya menghadap Ka'bah sebagai kiblat ketika ingin menjalankan shalat. Persoalannya kemudian, masihkah diwajibkan shalat di planet Mars? Lalu kemanakah arah kiblat bagi orang yang berada di planet Mars? Bagaimana cara mencari arah kiblatnya?

Dalam penelitian ini, akan diungkapkan nantinya sejauh mana ruang lingkup keberlakuan syari'ah sehingga menjadi jelas dimana saja kewajiban tersebut masih wajib dilaksanakan. Selanjutnya juga akan diungkapkan kemanakah arah kiblatnya dan bagaimana cara menentukan arah kiblatnya.

Dari kajian tersebut, ditemukan bahwa : (1) Syari'at masih tetap berlaku meskipun berada di planet Mars, sehingga orang yang berada di planet Mars masih dikenai kewajiban untuk melakukan shalat. (2) Arah kiblat bagi orang yang berada di planet Mars adalah Bumi atau proyeksi garis koordinat Bumi. (3) Untuk mengetahui arah atau azimuth bumi dari planet Mars, terlebih dahulu harus ditentukan waktu pengukuran dan koordinat geografis tempat di Mars yang akan diukur arah kiblatnya. Selanjutnya harus diperhitungkan nilai koordinat ekliptika planet Mars, Bumi, nilai koordinat Areosentrik Bumi, termasuk juga Nilai Jarak Bumi ke Mars, Nilai Asensiorekta Bumi dari Mars, Nilai Deklinasi Bumi dari Mars, nilai sudut elongasi bumi -Matahari, nilai Fraksi Iluminasi Bumi, Nilai Semidiameter Bumi dari Mars, nilai Lebar Piringan Bumi dari Mars, Nilai Equation of time, Nilai Azimuth dan
\end{abstract}


Altitude Bumi, Nilai dan Azimuth Matahari. Dari situ akan ditemukan dimana posisi Bumi dilihat dari Mars.

\section{Kata Kunci : Arah kiblat, Mars, Bumi, Perhitungan}

\section{A. Prolog}

Pada tanggal 14 Mei 2013, situs www.astronomi.us mengabarkan bahwa lebih dari 78.000 orang telah menaftarkan diri untuk pergi ke Mars. ${ }^{1}$ Angka ini terus bertambah. Sampai saat dilakukannya penelitian ini (tanggal 5 Februari 2014), sudah mencapai angka 200 ribu orang yang bersedia menjadi tukang "babat alas" di planet merah tersebut ${ }^{2}$. Mereka datang dari lebih dari 120 negara yang berbeda. Uniknya, 500 orang dari mereka adalah orang Arab Saudi yang notabenya adalah beragama Islam.

Yang menjadi perhatian di sini, misi Mars One ini bukan untuk perjalanan pulang pergi, namun lebih dari itu, mereka akan tetap tinggal di mars, tidak kembali ke Bumi. ${ }^{3}$ Itulah yang dikatakan Lansdorp. Karena menurutnya, misi Mars One ini ditujukan untuk membangun koloni manusia permanen di planet Mars. Jadi, mereka tidak akan kembali ke Bumi. Rencananya, misi kolonoi pertama akan dilangsungkan pada tahun 2023 dengan 4 orang yang akan dipilih dari sekian banyaknya pendaftar. Dilanjutkan dengan misi koloni kedua pada tahun 2025 dan berturut-turut 2 tahun sekali setelahnya.

Terlepas dari itu semua, kemungkinan adanya sebuah kehidupan di luar bumi telah diisyaratkan oleh al-Qur'an. Dalam surat ar-Ra'd ayat 15 disebutkan :

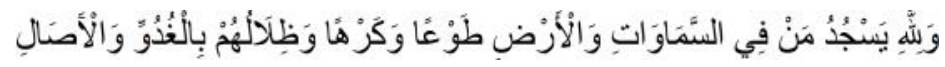

(Artinya : Dan semua sujud kepada Allah baik yang dilangit maupun yang di bumi, baik dengan kemampuan sendiri maupun terpaksa (dan sujud pula) bayang-bayang mereka, pada waktu pagi dan petang hari)(Ar-Ra'd:15)

Pemaikaian isim maushul "man" mengindikasikan bahwa makhluk hidup yang dimaksud adalah makhluk hidup yang berakal. Dan mereka pun mempunyai bayang-bayang, yang artinya bukan jin atau pun malaikat, namun makhluk hidup sejenis manusia. ${ }^{5}$ Mengenai manakah tempat yang di maksud kata as-samawat, diduga jawabannya adalah planet-planet yang tersebar di ruang angkasa luas di luar bumi. Yang mana tempat-tempat tersebut mesti mengandung beragam hal yang diperlukan bagi terwujudnya kehidupan, seperti air, oksigen, bahan makan dan lain sebagainya. ${ }^{6}$ Dan telah diketahui bahwa di ruang angkasa terdapat milyaran galaksi yang terbentuk dari bintang atau planet yang tidak terhitung jumlahnya. Setiap gugusan bintang ini tentu memiliki karakter-karakter yang serupa antara yang satu dengan lainnya, walaupun mestinya keadaan itu tidak persis sama. ${ }^{7}$ Karena itu,

\footnotetext{
${ }^{1}$ http://www.astronomi.us/2013/05/lebih-dari-78-ribu-orang-mendaftar.html, diakses pada tanggal 8 Januari 2014, jam : 20:28

${ }^{2}$ http://www.merdeka.com/teknologi/200-ribu-orang-siap-jadi-warga-planet-mars.html diakses pada tanggal 8 Januari 2014, jam : 21:05

${ }^{3}$ Op.cit.

${ }^{4}$ Kementrian Agama RI, Tafsir Ilmi Penciptaan Jagad Raya Dalam Prespektif Al-Qur'an dan Sains, Jakarta : PT. Sinergi Pustaka Indonesia, 2012, hal. 106

${ }^{5}$ Ibid, hal. 105

${ }^{6}$ Ibid, hal. 106

${ }^{7}$ Ibid
} 
adanya planet-planet yang keadaanya serupa dengan Bumi merupakan suatu keniscayaan yang tidak diragukan. Dengan demikian, adanya kehidupan di tempattempat tersebut sangat memungkinkan. ${ }^{8}$

Hal ini dibenarkan dengan adanya temuan-temuan dari para ilmuwan. NASA (Badan Antariksa Amerika Serikat) menyatakan tentang adanya kehidupan mikroskopis di planet Mars. ${ }^{9}$ Wahana Mars Reconnaissance Orbiter (MRO) yang saat ini sedang mengorbit planet Mars mengabadikan gambar adanya aliran aluvial yang terbentuk oleh air pada jutaan tahun yang lalu dengan memakai kamera HiRISE (High Resolution Imaging Science Experiment). Aliran ini ditemukan di sebuah daerah di dekat kawah Mojave di ekuator Mars ${ }^{10}$.

Bukti tersebut dikuatkan dengan temuan Curiosity, sebuah robot penjelajah Mars milik NASA. Curiosity menemukan adanya batuan/kerikil yang menempel pada batuan konglomerat sebagai hasil dari aliran air. Kerikil tersebut diperkirakan terbawa oleh aliran air dengan kecepatan sekitar 1 meter per detik dengan kedalaman bervariasi mulai dari se-mata kaki sampai se-pinggang orang dewasa. ${ }^{11}$

Rebecca Williams, ilmuwan penyelidik Curiosity mengatakan bahwa kerkil tersebut tidak dibawa oleh angin, namun dibawa oleh aliran air. ${ }^{12}$ Bukti tersebut ditemukan di sebelah utara dari tepi kawah Gale dan di bawah Gunung Aeolis Mons atau Mount Sharp. Sebelah utara kawah terdapat sebuah saluran bernama Peace Vallis yang mengalir ke saluran-saluran yang lebih kecil. ${ }^{13}$ Adanya air ini, menurut alQur'an mengindikasikan adanya makhluk hidup di tempat tersebut dan juga tempat tersebut bisa dijadikan sebagi tempat untuk hidup atau tempat yang mempunyai sumber kehidupan. Dalam surat an-Nur ayat 45 disebutkan :

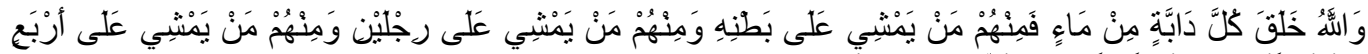

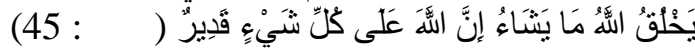

(Artinya : Dan Allah telah menciptakan semua jenis hewan dari air, maka sebagian dari hewan itu ada yang berjalan di atas perutnya dan sebagian berjalan dengan dua kaki sedang sebagian (yang lain) berjalan dengan empat kaki. Allah menciptakan apa yang dikehendaki-Nya, sesungguhnya Allah Maha Kuasa atas segala sesuatu). ${ }^{14}$

Dengan demikian possibility untuk bisa hidup di planet Mars sangatlah besar. Masalahnya kemudian, bagaimana dengan ketentuan-ketentuan syari'at yang pada waktu itu memakai paradigma al-ardh (bumi) saja. Sebagaimana yang tercerminkan dalam hadist yang diriwayatkan oleh Ibnu 'Abbas tentang arah kiblat. Dalam hadist tersebut disebutkan :

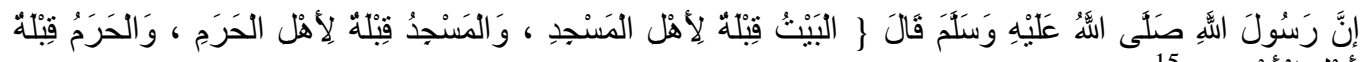

\footnotetext{
${ }^{8}$ Ibid

${ }^{9}$ Ibid, hal. 105

${ }^{10} \mathrm{http}: / /$ www.astronomi.us/2013/08/bukti-paling-nyata-air-pernah-ada-di.html

${ }_{11} \mathrm{http}: / /$ www.astronomi.us/2012/09/curiosity-temukan-batuan-yang-buktikan.html

12 Op.cit

${ }^{13}$ Ibid

${ }^{14}$ Kementrian Agama RI, Log.cit, hal. 105

${ }^{15}$ Muhammad bin Muhammad bin Muhammad bin 'Abdur Rahman Ar-Ra'ini, Mawahib Al-
} Jalil, Daru 'Alim al-Kutub, 2003, juz. 2, hal. 199 
(Artinya : Sesungguhnya Rasulullah SAW bersabda, "Baitullah (Ka'bah) adalah kiblat bagi orang yang berada di Masjidil Haram, dan Masjidil Haram adalah kiblat bagi orang yang berada di tanah haram (Makkah), dan tanah haram (Makkah) adalah kiblat bagi penduduk Bumi)

Dalam hadist tersebut tidak disebutkan secara eksplisit bagaimana kiblatnya orang yang berada di luar Bumi, seperti Mars misalnya.

Maka hal ini akan menjadi sebuah permasalahan jikalau dengan kecanggihan tekhnologi masa kini memungkinkan penduduk Bumi untuk berpindah ke planet Mars. Pertama, apakah bagi umat Islam yang berada di Mars masih dikenai kewajiban untuk melakukan shalat? Kalaupun iya, manakah arah kiblat tempat ia menghadap saat shalat? Pertanyaan-pertanyaan ini akan dibahas dalam penelitian ini dengan judul "Arah Kiblat Di Planet Mars".

\section{B. Antusiasme dan Prospek Hidup di Planet Mars}

Harun Yahya dalam bukunya "Pesona Di Angkasa Raya" menyebutkan bahwa hanya planet Bumi-lah satu-satunya planet yang memungkinkan adanya kehidupan. Selain itu, dia juga mengungkapkan bahwa tidak ada kehidupan di planet Mars.Planet Mars merupakan planet mati yang tidak pernah dibandingkan dengan Bumi. Alasanalasan yang dikemukakan adalah :

1. Atmosfir palent Mars merupakan campuran mematikan yang mengandung karbondioksida pekat;

2. Tidak ada air di sana ;

3. Suhu di planet Mars sekitar $-53^{\circ} \mathrm{C}\left(-63^{\circ} \mathrm{F}\right)$;

4. Terdapat angin yang sangat kuat serta badai pasir yang terjadi setiap saat. ${ }^{16}$

Namun dari itu, para ahli eksobiologi ${ }^{17}$ mempunyai analisis yang berbeda dengan apa yang disampaikan oleh Harun Yahya. Mereka meyakini bahwa beberapa bentuk kehidupan mungkin ada di Planet Mars. Pendapat ini didasarkan pada beberapa argumen yang mendasarinya, yaitu :

1. Radiasi ultraviolet mudah dihadang oleh rintangan fisik;

2. Oksigen, nitrogen dan air mungkin terdapat dalam jumlah yang cukup guna membantu kehidupan organisme yang kuat seperti bakteri dan lumut;

3. Adanya sebuah lapisan air yang tetap beku (bekuperma) di bawah permukaan tanah tampaknya mungkin dan mungkin meleleh di tempat-tempat tertentu dari waktu ke waktu sehingga dapat tersedia air buat benda hidup;

4. Nitrogen dapat saja terbentuk dalam jumlah kecil di dalam atmosfer; di dalam tanah juga mungkin terdapat garama-garam yang mengandung nitrogen;

5. Berdasarkan hasil uji coba labolatorium dengan berbagai keadaan lingkungan Mars tiruan, organisme-organisme seperti bakteri, ganggang, lumut, lumut padas, beberapa tanaman dari kelas yang lebih tinggi, dan serangga terbukti masih dapat hidup.

Dalam hal adanya kemungkinan kehidupan di luar Bumi, al-qur'an juga memberi isyarat akan hal ini. Dalam surat ar-Ra'd ayat 15 disebutkan :

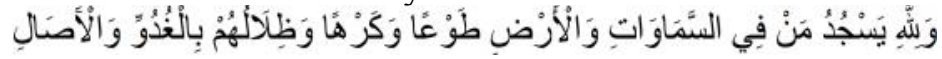

\footnotetext{
${ }^{16}$ Harun Yahya, Pesona Di Angkasa Raya, e-book.

${ }^{17}$ Eksobiologi secara harfiah berarti biologi luar (bumi), yatu ilmu yang lebih lanjut membahas asalusul kehidupan. Lihat artikel Richard S. Young berjudul Kehidupan di Dunia Lain dalam buku Ilmu Pengetahuan Populer, hal. 34
} 
(Artinya : Dan semua sujud kepada Allah baik yang dilangit maupun yang di bumi, baik dengan kemampuan sendiri maupun terpaksa (dan sujud pula) bayang-bayang mereka, pada waktu pagi dan petang hari)(Ar-Ra'd:15) ${ }^{18}$

Pemaikaian isim maushul "man" menunjukkan bahwa makhluk hidup yang dimaksud adalah makhluk hidup yang berakal. Dan mereka pun mempunyai bayangbayang, yang artinya bukan jin atau pun malaikat, namun makhluk hidup sejenis manusia. ${ }^{19}$ Mengenai manakah tempat yang di maksud kata as-samawat, diduga jawabannya adalah planet-planet yang tersebar di ruang angkasa luas di luar bumi. Yang mana tempat-tempat tersebut mesti mengandung beragam hal yang diperlukan bagi terwujudnya kehidupan, seperti air, oksigen, bahan makan dan lain sebagainya. ${ }^{20}$ Dan telah diketahui bahwa di ruang angkasa terdapat milyaran galaksi yang terbentuk dari bintang atau planet yang tidak terhitung jumlahnya. Setiap gugusan bintang ini tentu memiliki karakter-karakter yang serupa antara yang satu dengan lainnya, walaupun mestinya keadaan itu tidak persis sama. ${ }^{21}$ Karena itu, adanya planet-planet yang keadaanya serupa dengan Bumi merupakan suatu keniscayaan yang tidak diragukan. Dengan demikian, adanya kehidupan di tempat-tempat tersebut sangat memungkinkan. ${ }^{22}$

Terlepas dari itu, antusiasme penduduk Bumi untuk mencari kehidupan di luar Bumi, khususnya di planet Mars sangatlah tinggi. Ini terlihat dari upaya-upaya yang ditempuh mulai dari tahun 1961 sampai sekarang dan upaya-upaya yang dirancang untuk masa depan. Diantara upaya-upaya tersebut adalah :
a. Mars-1, Mars-2 dan Mars-3
b. Mariner 4
c. Viking Orbiter
d. Viking Eksperiment
e. Phoenix Lander, 2008
f. Mars Science Laboratory
g. Exo Mars
h. Misi Penjelajahan Mars 2020
i. Misi Pengambilan Sampel Planet Mars

\section{Ruang Lingkup Pemberlakuan Hukum Shalat}

Dalam surat al-Anbiya' ayat 107 disebutkan :

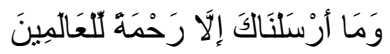

Artinya : Dan tiadalah Kami mengutus kamu, melainkan untuk (menjadi) rahmat bagi semesta alam.

Mengenai maksud dari kata "'alamiina” Ibnu Mandhur dalam Lisanul 'arab menyebutkan :

$$
\text { كلُه وقيل هو ما احتو اه بطنُ الفَلك }
$$

(Yang dimaksud 'alam adalah semua ciptaan Allah. Dan ada yang mengatakan bahwa 'alam adalah: segala sesuatu yang tercangkup dalam orbit)

$$
\text { التنزيل الحمد لله ربّّ العالمين قال ابن عباس رَبّ الجن و الإنس وقال قتادة رب الخلق كلهم }
$$

\footnotetext{
${ }^{18}$ Kementrian Agama RI, Tafsir Ilmi Penciptaan Jagad Raya Dalam Prespektif Al-Qur'an dan
} Sains, Jakarta : PT. Sinergi Pustaka Indonesia, 2012, hal. 106

${ }^{19}$ Ibid, hal. 105

${ }^{20}$ Ibid, hal. 106

${ }^{21}$ Ibid

${ }^{22}$ Ibid 
Dalam ayat "Alhamdulillahi rabbil 'alamin, Ibnu 'Abbas menafsirinya Tuhan jin dan manusia. Qatadah mengatakan bahwa yang dimaksud adalah Tuhan semua makhluk/ciptaan)

$$
\text { وروي عن و هب بن منبه أنه قال لله تعالى ثمانية عشر ألفَ عالَم الدنيا منها عالَّم }
$$

Dan diriwayatkan dari Wahab bin Manbah bahwasanya Nabi bersabda, "Allah ta'ala mempunyai 80.000 'alam dunia, diantara ada alam yang satu.

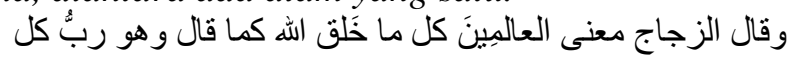

Az-zujaj mengatakan bahwa makna al-'alamiina adalah semua yang diciptakan oleh Allah sebagaimana ucapan bahwa Allah adalah tuhan segala sesuatu

Ibnu katsir dalam kitabnya tafsir Ibnu Katsir menyebutkan :

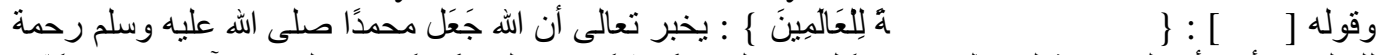

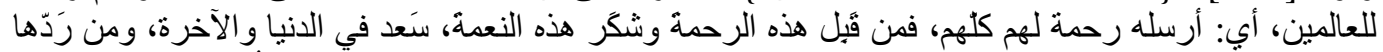

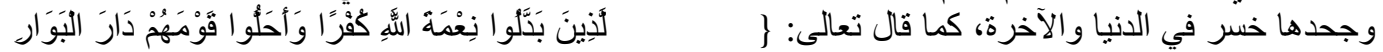

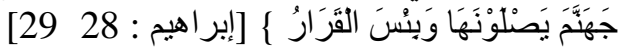

Firman Allah Ta'ala, "wa maa arsalnaaka illa rahmatan lil 'alamina” memberikan kabar bahwa Allah menjadikan Nabi Muhammad SAW. sebagai rahmat bagi semua alam, maksudnya ia diutus sebagai rahmat bagi semua alam. Barang siapa yang menerima rahmat ini dan mensyukuri nikmat ini, ia akan bahagia di dunia dan akhirat. Dan barang siapa yang menolak dan menetangnya, ia akan merugi di dunia dan akhirat sebagaimana firman Allah ta'ala: "Tidakkah kamu perhatikan orangorang yang telah menukar nikmat Allah dengan kekafiran dan menjatuhkan kaumnya ke lembah kebinasaan?, yaitu neraka jahannam; mereka masuk kedalamnya; dan itulah seburuk-buruk tempat kediaman.

Dari pemaparan di atas dapat diketahui bahwa dalam menafsirkan ayat "wa maa arsalnaaka illa rahmatan lil 'alamin" ada yang mengkaitkannya dengan dimensi personal, yakni manusia dan jin. Dan ada pula yang mengkaitkannya dengan dimensi ruang, yakni seluruh alam semesta yang tercakup dalam falak (orbit).

Dengan begitu berarti kewajiban melakukan peribadatan tidak terbatas pada tempat atau ruang tertentu, namun dimana pun kita berada, peribadatan tetap wajib dilaksanakan sebagaimana dalam tuntutan untuk bertakwa. Dalam hadist yang diriwayatkan oleh Imam Tirmidzi, disebutkan bahwa tuntutan untuk bertakwa tidak terbatas pada temat tertentu, akan tetapi wajib dilakukan dimanapun kita berada.

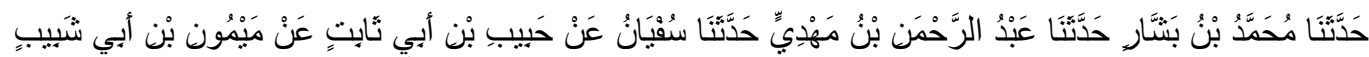

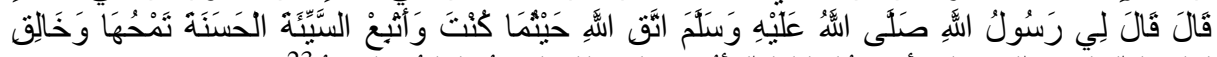

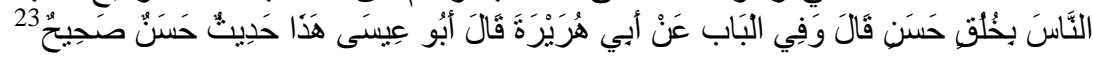

Kita diceritai oleh Muhammad bin Bassyar, kita diceritai oleh Abdurrahman bin Mahdi, kita diceeritai oleh Sufyan dari Habib bin Abi Tsabit dari Maimun dari Abi Syabib dari Abi Dzar, ia berkata, Rasulullah berkata padaku "Bertakwalah kalian kepada Allah dimanapun kalian berada, dan iringilah perbuatan buruk dengan perbuatan baik tentu akan menghapusnya dan bergaulah sesama manusia dengan akhlak yang baik. Dalam bab ini, dari Abi Hurairah, Abu Isa mengatakan bahwa hadist ini hadist Hasan dan Shahih.

${ }^{23}$ At-Tirmidzi, Sunan Tirmidzi, Maktabah Syamilah, Juz 7. Hal. 262 
Masalah ini dipertegas lagi dengan melihat filosofi penciptaan manusia. Dalam surat Adz-Dzariyat ayat 56 disebutkan bahwa manusia dan juga jin diciptakan tidak lain adalah untuk mengabdi, beribadah dan menyembah Allah.

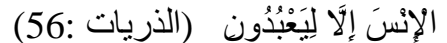 \\ " Dan Aku tidak menciptakan jin dan manusia melainkan supaya mereka menyembahKu"}

Maka dari itu, tujuan utama ini tidak bisa hilang hanya karena manusia berada di tempat yang berbeda dengan biasanya.

Shalat bisa menjadi haram dikerjakan bukan karena tempat pelaksanaanya, akan tetapi karena waktu pelaksanaanya. Dalam hal ini Zein Bin Ibrahim Bin Zein Bin Smith dalam kitab At-Taqiratus Sadidah Fi Masail al-Mufidah mengatakan bahwa saat-saat diharamkannya shalat itu ada 5, yang tiga berkaitan dengan dengan waktu dan yang 2 berkaitan dengan pekerjaan. 3 yang berkaitan dengan waktu yaitu :

1. Dari terbitnya Matahari sampai matahari setinggi tombak,

2. Dari waktu kulminasi Matahari (istiwa') sampai condong ke barat,

3. Dari menguningnya Matahari sampai tenggelam.

Adapun 2 hal yang berkaitan dengan pekerjaan yaitu :

1. Setelah mengerjakan shalat subuh sampai terbitnya Matahari,

2. Setelah mengerjakan shalat Ashar sampai tenggelamnya Matahari. ${ }^{24}$

Pentingnya shalat ini juga terlihat dari bagaimana Allah tetap mewajibkannya dalam kondisi apa pun dan bagaimana pun, baik dalam kondisi bepergian, sakit maupun perang. Orang yang sedang dalam kondisi bepergian, tetap wajib melakukan shalat meskipun boleh dengan dijamak maupun diqoshor. Orang yang sedang dalam kondisi sakit tetap wajib melakukan shalat meskipun dengan duduk ${ }^{25}$, atau tidur miring atau tidur terlentang atau dengan isyarat kelopak mata atau melakukan rukunrukun shalat di dalam hati ${ }^{26}$. Dan orang yang sedang dalam kondisi perang sesengit apapun itu, tetap masih wajib melakukan shalat, meskipun sebisanya saja, tidak seperti dalam kondisi normal, yaitu dengan memberikan isyarat ketika ruku' atau sujud dengan mengatur posisi yang lebih rendah jika sujud dan agak tinggi jika ruku', bila memungkingkan. Hal ini dilakukan dalam kondisi perang yang sudah tidak teratur, sudah bercampur aduk antara teman dan musuh. ${ }^{27}$

Tidak hanya itu, pentingnya shalat ini bisa dilihat dari bagaimana Allah memberikan ancaman terhadap orang yang meninggalkan kewajiban ini. Dalam sebuah hadist Nabi Muhammad SAW bersabda :

من ترك الصلاة لقي الله وهو عليه غضبان 28 Barang siapa yang meninggalkan shalat, Allah akan menemuinya dalam keadaan marah.

Dalam hadist lain beliau juga bersabda :

$$
\text { عمله و برئت منه ذمّة الله حتّى ير اجع اللّه عزّ وجلّ توبة }
$$

\footnotetext{
${ }^{24}$ Zein Bin Ibrahim Bin Zein Bin Smith, At-Taqiratus Sadidah Fi Masail al-Mufidah, Surabaya : Darul 'Ulum al-Islamiyyah, 2006, hal.192-193

${ }^{25}$ Syeikh Muhammad Bin Qasim, Fathul Qarib, Surabaya : Nurull Huda, tt, hal. 13

${ }^{26}$ Zein Bin Ibrahim Bin Zein Bin Smith, opcit, hal. 214

${ }^{27}$ Zein Bin Ibrahim Bin Zein Bin Smith, ibid, hal. 355

${ }^{28}$ Zein Bin Ibrahim Bin Zein Bin Smith, ibid, hal. 360

${ }^{29}$ Zein Bin Ibrahim Bin Zein Bin Smith, ibid.
} 
Barang siapa yang sengaja meninggalkan shalat, Allah akan melebur amal perbuatannya dan membebaskan tanggungan atas dirinya sehingga ia kembali kepada Allah dalam keadaan taubat.

Lebih ekstrimnya lagi, Nabi Muhammad mengatakan bahwa perbedaan antara orang muslim dan kafir adalah shalat. Ketika ia meninggalkan shalat, ia tak ubahnya seperti orang kafir.

بين الرجل و بين الكفر ترك الصيّلاة30

(Perbedaan) antara orang laki-laki (muslim) dan kafir adalah meninggalkan shalat.

Maka dari itu, bisa disimpulkan bahwa kewajiban melakukan shalat tetaplah melekat pada diri umat Islam dimanapun ia berada. Kewajiban shalat bisa berubah hukumnya ketika dikaitkan dengan waktu, bukan tempat pelaksanaanya. Dari situ, penulis menyimpulkan bahwa umat Islam masih tetap dikenai kewajiban menjalankan shalat meskipun di planet Mars. Hal ini juga sebagaimana yang dilakukan oleh Dr. Sheikh Muszaphar Shukor ketika mengikuti proyek ISS (Internasional Space Station). Meskipun dia tidak sedang berada di Bumi, dia tetap melakukan ibadah shalat.

\section{Identifikasi Arah Kiblat di Planet Mars}

Sebagaimana yang telah kita ketahui bahwa pada dasarnya, shalat haruslah dilakukan dengan menghadap kiblat, yakni Ka'bah. Dalam surat Al-Baqarah ayat 144 Allah berfirman :

$$
\begin{aligned}
& \text { قد نرى تقلب وجهاك فى السماء فلنولينك قبلة ترضها فول وجهاك شطر المسجد الحر ام وحيث ما كنتم فولوا }
\end{aligned}
$$

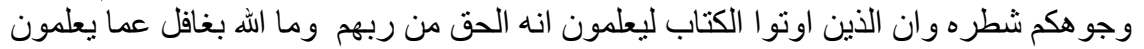

Dalam suatu hadist yang diriwayatkan oleh Malik juga disebutkan :

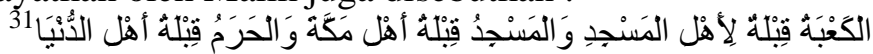
(Ka'bah adalah kiblatnya orang yang berada di Masjidil Haram. Masjidil Haram adalah kiblatnya orang yang berada di Makkah. Tanah Haram (Makkah) adalah kiblatnya orang sedunia)

Dalam hadist lainnya yang diriwayatkan oleh Imam Baihaqi dalam kitab sunannya disebutkan :

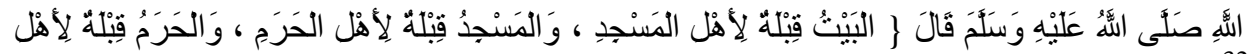

$$
{ }^{32}\{
$$

(Sesungguhnya Rasulullah SAW bersabda : Baitullah (Ka'bah) adalah kiblatnya orang yang berada di Masjidil Haram. Masjidil Haram adalah kiblatnya orang yang berada di Makkah. Tanah Haram (Makkah) adalah kiblatnya orang di Bumi)

Ini berarti bahwa kiblat bagi orang yang berada di tempat tertentu adalah Ka'bah atau wilayah yang melingkupi ka'bah. Jadi, mafhum muwafaqoh-nya adalah kiblat bagi orang yang berada di planet Mars adalah wilayah yang melingkupi Ka'bah dilihat dari planet Mars yakni Bumi atau proyeksi arah Bumi jikalau Bumi tidak tampak.

Dan dengan mengingat perkembangan ilmu pengetahuan yang sedemikian hingga, tidak ada beban (masyaqqoh) yang berarti ketika dituntut untuk menghadap ke kiblat saat akan melaksanakan shalat di planet Mars. Dan kompleksifitas perhitungan juga bisa disederhanakan dengan memanfaatkan program microsft excel atau kalkulator. Adapun langkah-langkah yang harus ditempuh dalam perhitungannya yaitu :

\footnotetext{
${ }^{30}$ Zein Bin Ibrahim Bin Zein Bin Smith, ibid.

${ }^{31}$ Al-Qarafi, Anwarul Baruq, Maktabah Syamilah, Juz. 4, hal.75

${ }^{32}$ Ibid, hal. 76
} 
1. Menentukan waktu pengukuran dan koordinat geografis tempat yang akan diukur arah kiblatnya

2. Mencari Nilai Bujur Ekliptika (Ecliptic Longitude) planet Mars

3. Mencari Nilai Lintang Ekliptika (Ecliptic Latitude) planet Mars

4. Mencari Nilai Jarak (Distance) planet Mars ke Matahari

5. Mencari Nilai Bujur Ekliptika (Ecliptic Longitude) Heliosentris planet Bumi

6. Mencari Nilai Lintang Ekliptika (Ecliptic Latitude) Heliosentris planet Bumi

7. Mencari Nilai Jarak (Distance) planet Bumi ke Matahari

8. Mencari Nilai Julian Date, bilangan abad julian dan bilangan milenium julian

9. Mencari Nilai Jarak Bumi ke Mars

10. Mencari Nilai Asensiorekta Bumi dari Mars

11. Mencari Nilai Deklinasi Bumi dari Mars

12. Mencari nilai sudut elongasi bumi -Matahari

13. Mencari Nilai Fraksi Iluminasi Bumi

14. Mencari Nilai Semidiameter Bumi dari Mars

15. Mencari Nilai Lebar Piringan Bumi dari Mars

16. Mencari Nilai Koordinat Areosentrik Bumi yang meliputi bujur areosentrik, lintang areosentrik

17. Mencari Nilai Equation of time, dan nantinya akan ditemukan

18. Nilai Azimuth dan Altitude Bumi

\section{E. Penutup}

Dari pemaparan yang sudah diungkapkan dalam bab-bab sebelumnya, dapat disimpulkan bahwa :

1. Orang yang berada di planet Mars masih dikenai kewajiban untuk melakukan ibadah shalat

2. Arah Kiblat bagi orang yang berada di planet Mars adalah arah dimana bumi berada, karena di bumilah letak ka'bah atau garis proyeksi arah bumi.

3. Cara untuk mengetahui arah kiblat di planet Mars yaitu dengan mengetahui arah atau azimuth bumi dari planet Mars. Terlebih dahulu, harus ditentukan waktu pengukuran dan koordinat geografis tempat di Mars yang akan diukur arah kiblatnya. Selanjutnya harus diperhitungkan nilai koordinat ekliptika planet Mars, Bumi, nilai koordinat Areosentrik Bumi, termasuk juga nilai jarak Bumi ke Mars, nilai asensiorekta Bumi dari Mars, nilai deklinasi Bumi dari Mars, nilai sudut elongasi bumi -Matahari, nilai Fraksi Iluminasi Bumi, Nilai semidiameter Bumi dari Mars, nilai lebar piringan Bumi dari Mars, nilai equation of time, nilai azimuth dan altitude Bumi, nilai dan azimuth Matahari. Dari situ akan ditemukan dimana posisi Bumi dilihat dari Mars.[] 


\section{Daftar Pustaka}

Al-Qarafi, Anwarul Baruq, Maktabah Syamilah, Juz. 4

Ar-Ra'ini, Muhammad bin Muhammad bin Muhammad bin 'Abdur Rahman, Mawahib Al-Jalil, Daru 'Alim al-Kutub, 2003, juz. 2

Artikel Richard S. Young berjudul Kehidupan di Dunia Lain dalam buku Ilmu Pengetahuan Populer

Kementrian Agama RI, Tafsir Ilmi Penciptaan Jagad Raya Dalam Prespektif AlQur'an dan Sains, Jakarta : PT. Sinergi Pustaka Indonesia, 2012

Smith, Zein Bin Ibrahim Bin Zein Bin, At-Taqiratus Sadidah Fi Masail al-Mufidah, Surabaya : Darul 'Ulum al-Islamiyyah, 2006

Qasim, Syeikh Muhammad Bin, Fathul Qarib, Surabaya : Nurull Huda, tt

Yahya, Harun, Pesona Di Angkasa Raya, e-book.

http://www.astronomi.us/2013/05/lebih-dari-78-ribu-orang-mendaftar.html

http://www.merdeka.com/teknologi/200-ribu-orang-siap-jadi-warga-planet-mars.html

http://www.astronomi.us/2013/08/bukti-paling-nyata-air-pernah-ada-di.html

http://www.astronomi.us/2012/09/curiosity-temukan-batuan-yang-buktikan.html 